\title{
Overview of Silicon Carbide Technology: Device, Converter, System, and Application
}

\author{
Fei (Fred) Wang and Zheyu Zhang
}

\begin{abstract}
This paper overviews the silicon carbide ( $\mathrm{SiC})$ technology. The focus is on the benefits of $\mathrm{SiC}$ based power electronics for converters and systems, as well as their ability in enabling new applications. The challenges and research trends on the design and application of $\mathrm{SiC}$ power electronics are also discussed
\end{abstract}

Index Terms- $\mathrm{SiC}$ power semiconductors, $\mathrm{SiC}$ based converters.

\section{INTRODUCTION}

A $\mathrm{T}$ the heart of modern power electronics converters are power semiconductors switching devices. Today's power semiconductor devices are dominated by the mature and well established silicon ( $\mathrm{Si}$ ) technology. Since the advent of Si thyristors in 1957, many Si based switching devices have been developed to meet different application and performance needs. The most popular Si switching devices are insulated-gate bipolar transistors (IGBT) and power metal-oxide-field-effect transistors (MOSFET), with IGBT for high voltage, high power, and low frequency applications, and MOSFET for low voltage, low power and high frequency applications. Thyristors and their derivatives such as integrated-gate-commutated thyristors (IGCT) are still used in special high power applications.

Si power semiconductor devices have gone through many generations of development in the last 50 years and are approaching material theoretical limitations in terms of blocking voltage, operation temperature, and conduction and switching characteristics. Due to limited performance, the highest voltage rating of the state-of-art commercial Si IGBT has been $6.5 \mathrm{kV}$ for the last 15 years. There are no commercial Si based devices with junction temperature capability above $175^{\circ} \mathrm{C}$. These intrinsic physical limits become a barrier to achieving higher performance power conversion.

The emergence of wide bandgap (WBG) semiconductor devices promises to revolutionize next-generation power

Manuscript received December 10,2016. This work made use of the Engineering Research Center Shared Facilities supported by the Engineering Research Center Program of the National Science Foundation and DOE under NSF Award Number EEC-1041877 and the CURENT Industry Partnership Program.

F. Wang and Z. Zhang are with CURENT \& the Department of Electrical Engineering and Computer Science, University of Tennessee, Knoxville, TN 37996-2250 USA (e-mail: fred.wang@utk.edu).

Digital Object Identifier 10.24295/CPSSTPEA.2016.00003 electronics converters. Compared with Si devices, WBG devices feature high breakdown electric field, low specific on-resistance, fast switching speed and high junction temperature capability. All of these characteristics are beneficial for the efficiency, power density, specific power, and/or reliability of power electronics converters. The WBG devices under rapid development and commercialization include silicon carbide $(\mathrm{SiC})$ and gallium nitride $(\mathrm{GaN})$ devices, with $\mathrm{SiC}$ mainly targeting high voltage high power $(600 \mathrm{~V}$, kilowatts or above) applications, and $\mathrm{GaN}$ for low voltage low power (600 V, kilowatts or below) applications [1]. This paper focuses on $\mathrm{SiC}$ technology.

$\mathrm{SiC}$ devices can improve and impact power electronics in several ways [2]: 1) At converter level, through substituting Si devices directly or simplifying circuit topologies, $\mathrm{SiC}$ devices can improve converter efficiency, reduce cooling needs, and reduce active and passive component numbers and size, with their high voltage, low loss and fast switching capabilities; 2) At system level, $\mathrm{SiC}$ based converters can have better dynamic performance and more system functionalities as a result of their high frequency capability and high control bandwidth enabled by fast switching speed, and 3) SiC can enable new applications, such as high-efficiency high-density solid-state transformers (SST) and high speed motor drives. A number of commercial and research prototype converters using $\mathrm{SiC}$ devices have been developed with promising results on significantly improved efficiency and power density [3]-[49].

The extremely fast switching and other superior characteristics of $\mathrm{SiC}$ devices have nonetheless also posed severe challenges to their applications. Pervasive $d v / d t$ and $d i /$ $d t$ slew rates of up to $100 \mathrm{~V} / \mathrm{ns}$ and $10 \mathrm{~A} / \mathrm{ns}$, augmented electromagnetic interference (EMI) emissions, single-device blocking voltages as high as tens of $\mathrm{kV}$ with corresponding insulation requirements, switching frequencies in the $100 \mathrm{~s}$ of $\mathrm{kHz}$ range, and junction temperatures surpassing $200{ }^{\circ} \mathrm{C}$, have called for a comprehensive reformulation of design procedures developed for Si-based power electronics. Addressing these design and application issues are critical to the adoption and success of $\mathrm{SiC}$ power electronics.

This paper overviews the $\mathrm{SiC}$ technology and recent advances on devices, converters, systems, and applications. The focus is on the benefits of $\mathrm{SiC}$ based power electronics for converters and systems, as well as their ability in enabling new applications. The challenges and research trends on the design and application of $\mathrm{SiC}$ power electronics are also discussed. 


\section{SiC Power Semiconductor Devices and Modules}

The discussion in this section focuses on the characteristics of $\mathrm{SiC}$ devices versus their $\mathrm{Si}$ counterparts, status of $\mathrm{SiC}$ power semiconductors as well as $\mathrm{SiC}$ version of the intelligent power modules.

\section{A. Introduction of $\mathrm{SiC}$ in Comparison to $\mathrm{Si}$}

WBG refers to electronic energy band gaps significantly larger than one electron-volt (eV). SiC materials have several characteristics that make them attractive compared to narrow bandgap Si for power electronics converters. Fig. 1 highlights some key material properties of $\mathrm{SiC}$ semiconductor candidates as compared to traditional $\mathrm{Si}$ [50]. Generally speaking, for $\mathrm{SiC}$ material, the energy gap, breakdown electric field, thermal conductivity, melting point, and electron velocity are all significantly higher. These characteristics allow $\mathrm{SiC}$ semiconductor based power devices to operate at much higher voltage, switching frequency and temperature than $\mathrm{Si}$ [1], [51], [52].

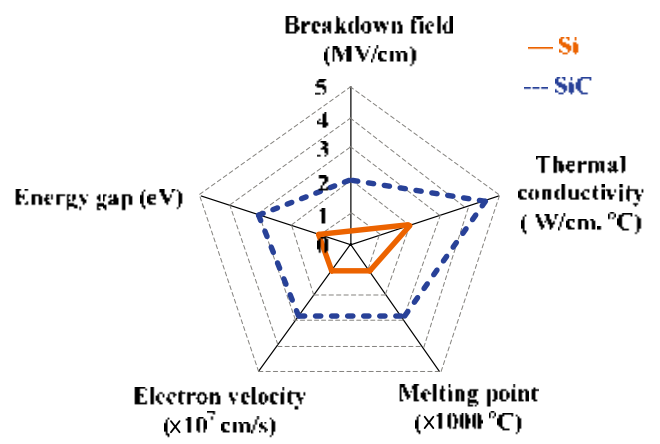

Fig. 1. Summary of $\mathrm{Si}$ and $\mathrm{SiC}$ relevant material properties [50].

For example, with the breakdown field higher than that of $\mathrm{Si}$, a thinner drift layer with a higher doping concentration can be used for $\mathrm{SiC}$ power devices at the same blocking voltage. For unipolar device such as Schottky diodes and MOSFETs, the combination of thinner blocking layer and higher doping concentration yields a lower specific onresistance compared with Si majority carrier devices.

The fast switching-speed capability of $\mathrm{SiC}$ devices can be expected due to higher breakdown field and electron velocity. First, with lower on-resistance at the same breakdown voltage, a reduced chip size is achieved in $\mathrm{SiC}$ unipolar devices such as MOSFET. Considering the tradeoff between thinner drift region and smaller chip size, the junction capacitance of SiC MOSFETs is still lower than that of the Si counterparts, therefore the switching speed becomes faster. Second, minority carriers are swept out of the depletion region at the saturated drift velocity during the turn-off transient. The electron saturated drift velocity of $\mathrm{SiC}$ is higher than that of $\mathrm{Si}$, leading to an increased switching speed of SiC devices.

Additionally, the excellent thermal conductivity allows $\mathrm{SiC}$ dissipated heat to be readily extracted from the device.
Hence, a larger power can be handled by the device at a given junction temperature. Also, higher thermal conductivity together with wide bandgap makes it possible for $\mathrm{SiC}$ devices to work at high temperature.

In summary, $\mathrm{SiC}$ based power devices offer low specific on-state resistance, fast switching speed, and high operating temperature and voltage capabilities.

\section{B. Status of SiC Devices}

This subsection summarizes available information on $\mathrm{SiC}$ power devices, including device types, voltage/current ratings, status of commercialization, as well as the latest trend of $\mathrm{SiC}$ device development. Note that the hybrid power modules consisting of Si active switches and SiC Schottky barrier diodes (SBDs), which have been commercially available, are not focused in the following discussion.

The availability of high quality $\mathrm{SiC}$ wafers allows a reasonable yield of large-area $\mathrm{SiC}$ power devices. Currently, $150 \mathrm{~mm}$ or 6 inch $\mathrm{SiC}$ wafers are commercially available [53]. Fig. 2 summarizes the status of $\mathrm{SiC}$ based power devices, including Schottky diodes, PIN diodes, MOSFETs, junction gate FETs (JFETs), IGBTs, bipolar junction transistors (BJTs), and thyristors with the voltage range from $400 \mathrm{~V}$ to $22.6 \mathrm{kV}$. It is observed that the low voltage (from $400 \mathrm{~V}$ to $1700 \mathrm{~V}) \mathrm{SiC}$ devices are becoming commercially available. Among them, the current rating per die approaches up to $100 \mathrm{~A}$, and with multiple dies in parallel, state-ofart $\mathrm{SiC}$ power modules on market can deliver hundreds of amperes current. On the other hand, the high voltage $\mathrm{SiC}$ (referred here as $3.3 \mathrm{kV}$ and above) are generally in developmental stages with limited commercial availability and small current rating per die [54].

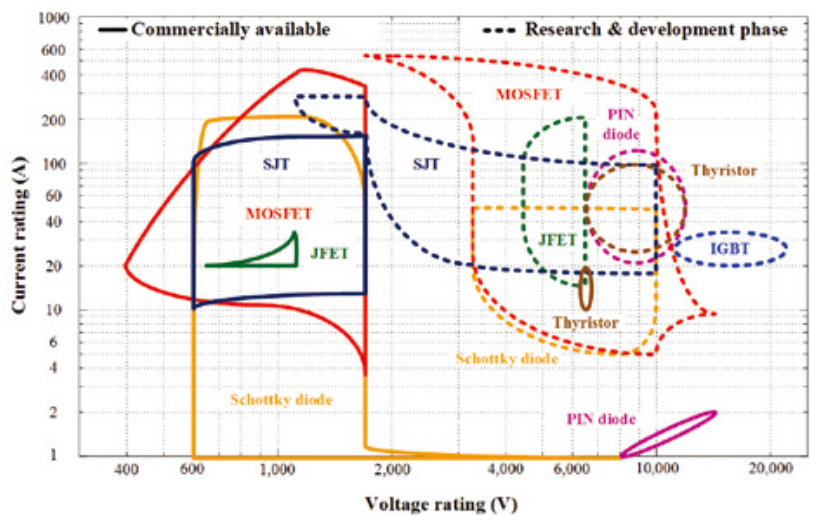

Fig. 2. Summary of status of $\mathrm{SiC}$ power devices [55]-[65].

Currently SiC MOFETs are the most developed active switches, with some JFETs, IGBTs, BJTs, and thyristors also available. For $\mathrm{SiC}$ diodes, at low breakdown voltage $(<1700 \mathrm{~V})$, SBDs are popular since they show extremely high switching speed and low on-state loss. But high leakage current and low blocking voltage limit their utilization in high voltage applications. PIN diodes and Junction Barrier Schottky (JBS) diodes are preferred in high voltage applications. Compared with PIN diodes, JBS diodes have 
excellent reverse recovery characteristic but poor static performance, making them suitable as anti-parallel diodes of active switches.

$\mathrm{SiC}$ power devices are developing rapidly. Compared with the data summarized in [2] a year ago, a few updates are highlighted as follows

\section{1) Increased Current Ratings and More Available Voltage Ratings}

Current ratings have been significantly improved at both die level and power module level under wide voltage ratings. For example, $650 \mathrm{~V} / 17 \mathrm{~m} \Omega$ discrete $\mathrm{SiC}$ MOSFET has been released with the current rating of $118 \mathrm{~A}$ at room temperature [55], which is comparable with the current rating of the state-of-the-art 650-V C7 Si CoolMOS on the market. Also, at medium voltage (MV) level, several large current power modules have been developed and demonstrated, including but not limited to $1.7 \mathrm{kV} / 550 \mathrm{~A}, 3.3 \mathrm{kV} / 180 \mathrm{~A}, 10 \mathrm{kV} / 240 \mathrm{~A}$ $\mathrm{SiC}$ MOSFETs based phase-leg power modules, and $6.5 \mathrm{kV} /$ 200 A SiC JFETs based phase-leg power modules [66], [67].

More voltage ratings are available mainly due to the application orientated consideration. One example is that a $1000 \mathrm{~V} \mathrm{SiC} \mathrm{MOSFET} \mathrm{has} \mathrm{been} \mathrm{released} \mathrm{recently} \mathrm{targeting}$ the electric vehicle application. Compared with $900 \mathrm{~V}$ and $1200 \mathrm{~V}$ voltage ratings, which are typical values for traditional Si devices, a dedicated $1000 \mathrm{~V} \mathrm{SiC} \mathrm{MOSFET} \mathrm{is}$ developed to achieve better tradeoff between performance (e.g. switching and conduction loss) and reliability (e.g. adequate voltage margin) [61]. As expected, with the acceleration of acceptance and adoption of $\mathrm{SiC}$ devices in industrial products, $\mathrm{SiC}$ manufacturers may be willing to develop more dedicated power semiconductors to best serve specific markets.

\section{2) Improved Packaging Techniques}

Advanced packaging techniques have been adopted for $\mathrm{SiC}$ devices for parasitic minimization, weight/size reduction, and high temperature operation.

For example, TO-247-4 pin package with separated Kelvin source has been utilized for discrete SiC MOSFETs at $1000 \mathrm{~V}$ and $1200 \mathrm{~V}$ levels [56], [61]. Thanks to the Kelvin source connection and its resultant lower common source inductance, the switching performance can be greatly improved with fast switching and low loss. Also, power modules with $<5 \mathrm{nH}$ parasitic inductance are developed for 1200-1700 V power modules with more than 400 A current capability [61], [65]. Additionally, ultra-light $\mathrm{SiC}$ power modules based on Easy1B PressFIT package are available for high density power conversion system [56]. Furthermore, high temperature packaging techniques are employed so as to allow commercially available $\mathrm{SiC}$ devices (e.g. Schottky diodes and supper junction transistors) to operate up to 210 ${ }^{\circ} \mathrm{C}$ [57].

\section{3) Availability of More Power Module Configuration}

In addition to the phase-leg power module, more options with respect to the configuration of power modules are available, such as boost chopper, buck chopper, full bridge, three-level neutral point clamped (NPC), threelevel T-type, triple phase-leg [59]. With this, users are able to more conveniently develop high performance power electronics circuits based on different topologies for various applications.

\section{4) Enhanced Short-circuit Withstand Capability}

Short circuit withstand capability is challenging for tiny and fast $\mathrm{SiC}$ devices [68]-[71]. Compared with traditional Si devices with $>10 \mu$ s short circuit withstand time, the typical short circuit withstand time of SiC MOSFETs is on the order of $1 \mu \mathrm{s}$. Recently, an enhanced short circuit capability SiC MOSFETs has been developed at MV level $(>3.3 \mathrm{kV})$. It is demonstrated that these new devices are capable of sustaining short circuit current up to $13 \mu \mathrm{s}$, which significantly benefits the reliable operation of SiC MOSFETs for voltage source based high power conversion system [66].

5) Better SiC MOSFET's Body Diode Performance and Trend of Eliminating SBDs in Power Modules

The body diode of the SiC MOSFET is structurally similar to the p-n junction diode formed in the body of a $\mathrm{Si}$ MOSFET. The lifetime of minority carriers in $\mathrm{SiC}$ is shorter than $\mathrm{Si}$, so the reverse recovery charge is reduced.

To mitigate the reverse recovery induced by MOSFET's body diode, a dedicated SiC SBD is generally added. However, considering the charging of SBD junction capacitance, employing an SBD in parallel does not necessarily result in low total switching energy loss. Specifically, at room temperature, the charging of SBD junction capacitance is greater than reverse recovery charge introduced by MOSFET's body diode [72]. Under elevated temperature, reverse recovery charge was observed to increase significantly; as a result, the switching energy loss may be higher as compared to that with SBD case. Recently, it is demonstrated that for the latest generation Wolfspeed $\mathrm{SiC}$ MOSFETs, at $150{ }^{\circ} \mathrm{C}$, the total switching energy loss without SBD does not exceed the loss with employing SBD [72]. Therefore, under wide operating range, the excellent switching performance can be achieved by SiC MOSFET without the extra SBD. Regarding the conduction loss, the channel of SiC MOSFETs, instead of its body diode, can efficiently conduct reverse current. In the end, the penalty without antiparallel SBD with respect to efficiency is limited.

Furthermore, reduced size and cost due to the lack of SBDs in power module can improve the power density and cost of overall power conversion system. Accordingly, it is observed that there is a trend of eliminating SBDs in $\mathrm{SiC}$ based power modules [65].

\section{SiC Intelligent Power Module}

Intelligent power modules (IPMs) are advanced power conversion units that combine power semiconductor chips with optimized gate drive and protection circuitry, such as 
over-current (OC), short-circuit (SC), over temperature (OT), and under voltage lock out (UVLO). The compact, easily assembled IPMs can be beneficial to reducing system size/ weight, cost, and time to market, and have been successfully applied for Si based high power conversion system [73].

A similar concept is being leveraged to $\mathrm{SiC}$ power semiconductors by different approaches. By replacing Si devices with $\mathrm{SiC}, \mathrm{SiC}$ based IPMs are starting to be commercially available [74]. Also, several gate drives optimized for the commercial-off-the-shelf $\mathrm{SiC}$ modules were developed and released recently [75], [76]. Although gate drive is not packaged with power module in an integrated fashion, the basic function of the IPMs defined above can be achieved. More versions of $\mathrm{SiC}$ based power module integrated with gate drive have been investigated and demonstrated [77]-[80]. They are generally in developmental stages.

TABLE I summarizes the state-of-the-art SiC IPMs. Note that the direct replacement of $\mathrm{Si}$ devices by $\mathrm{SiC}$ offers limited improvements in actual power electronics circuit as

TABLE I

Status of the State-OF-The-Art SiC IPMs

\begin{tabular}{|c|c|c|c|c|}
\hline No. & Manufacturer/Model & Description & Circuit & Special consideration for $\mathrm{SiC}$ \\
\hline 1 & $\begin{array}{l}\text { Powerex [74] } \\
\text { PMF75CL1A120 }\end{array}$ & SiC six pack IPM & Three-phase & Short-circuit protection, soft shutdown \\
\hline 2 & $\begin{array}{l}\text { Cree (now Infineon) [75] } \\
\text { CGD15HB62LP }\end{array}$ & $\begin{array}{l}\text { Gate drive board optimized for } \\
\mathrm{SiC} \text { modules }\end{array}$ & Phase-leg & High common mode $(\mathrm{CM})$ transient immunity \\
\hline 3 & $\begin{array}{l}\text { Agile Switch [76] } \\
\text { EDEM3 }\end{array}$ & $\begin{array}{l}\text { Gate drive board optimized for } \\
\mathrm{SiC} \text { modules }\end{array}$ & Phase-leg & 2-level turn-off driving, multi-level shutdown \\
\hline 4 & $\begin{array}{l}\text { Univ. of Tennessee [77] } \\
\text { Research \& development }\end{array}$ & $\begin{array}{l}\text { Power module integrated with } \\
\text { gate drive in board level }\end{array}$ & Phase-leg & $\begin{array}{l}\text { High temperature, low parasitics and } \\
\text { fast switching, fast short-circuit protection }\end{array}$ \\
\hline 5 & $\begin{array}{l}\text { Virginia Tech [78] } \\
\text { Research \& development }\end{array}$ & $\begin{array}{l}\text { Power module integrated with } \\
\text { gate drive in board level }\end{array}$ & Phase-leg & $\begin{array}{l}\text { High temperature, decoupling capacitor built in, } \\
\text { low parasitic and fast switching }\end{array}$ \\
\hline 6 & $\begin{array}{l}\text { North Carolina State Univ [79] } \\
\text { Research \& development }\end{array}$ & $\begin{array}{l}\text { Power module integrated with } \\
\text { gate drive in module level }\end{array}$ & Phase-leg & $\begin{array}{l}\text { Decoupling capacitor built in, low parasitics } \\
\text { and fast switching }\end{array}$ \\
\hline 7 & $\begin{array}{l}\text { Fraunhofer [80] } \\
\text { Research \& development }\end{array}$ & $\begin{array}{l}\text { Device chips integrated with } \\
\text { gate drive in board level }\end{array}$ & Phase-leg & $\begin{array}{l}\text { Decoupling capacitor built in, low parasitics } \\
\text { and fast switching, high CM transient immunity }\end{array}$ \\
\hline
\end{tabular}

compared to the inherent capability offered by $\mathrm{SiC}$ materials. Therefore, special design considerations of SiC IPMs have to be given, which are highlighted in TABLE I as well.

\section{SiC Based Power Electronics and Their Benefits}

Thanks to superior characteristics offered by $\mathrm{SiC}$ at power semiconductor device and module level, $\mathrm{SiC}$ based power electronics can be significantly beneficial from converter level and system level. More importantly, with much enhanced capability, $\mathrm{SiC}$ based power electronics are able to replace or enhance conventional functions performed by electromagnetic or electromechanical devices, leading to $\mathrm{SiC}$ enabled new applications.

This section focuses on the benefits achieved by utilizing $\mathrm{SiC}$ in power electronics converters from different aspects along with several examples for effectiveness demonstration.

\section{A. Converter Level Benefits}

Converter level benefits mainly include improved efficiency, smaller size and lighter weight, enhanced reliability, and reduced cost. They can be realized mainly in the following three ways

\section{1) Substitution of Si PIN Diodes with SiC Schottky Diodes}

Without any other modification to power converters, the excellent reverse recovery characteristics of SiC Schottky diodes lead to less switching loss. It is reported that the substitutions of Si PIN diodes with SiC Schottky diodes in applications using $600 \mathrm{~V}$ and $1200 \mathrm{~V}$ devices enabled more than $50 \%$ switching loss reduction [81]. As a result, improved efficiency and reduced cooling requirement can be achieved. For example, based on a $55-\mathrm{kW}$ three-phase inverter in motor drives, test results show that, by merely replacing Si PIN diodes with their SiC Schottky diode counterparts, the losses of an inverter decrease up to $10.7 \%$ under motoring mode and $12.7 \%$ under regeneration mode [82].

Alternatively, with the given loss budget, increased switching frequency and reduced passive components need can also be realized. Since 2001 when SiC SBDs became commercially available, they have been successfully employed in many products and demonstrated the expected performance in terms of improved efficiency and reliability [1]. Also, hybrid power modules consisting of Si IGBTs or MOSFETs with SiC SBDs are commercially available by multiple suppliers on the market [56], [60].

\section{2) Substitution of Si Active Switches with SiC Devices}

In addition to the mitigated reverse recovery, low onstate resistance and fast switching-speed capability of $\mathrm{SiC}$ active switches can further reduce power loss, therefore improve power conversion efficiency. Together with high 
operating temperature of $\mathrm{SiC}$ devices, they can also lead to reduced cooling requirement. Moreover, they can lead to high switching frequency and therefore reduced passive components need. In the end, converter power efficiency, power density, and/or temperature capability can be improved.

For example, in the data center power supply system, a $7.5 \mathrm{~kW}$ all-SiC three-phase buck rectifier was developed and demonstrated with $98.54 \%$ efficiency tested at full load, approximately $70 \%$ less loss than Si IGBT based converter. Moreover, $\mathrm{SiC}$ version is $10 \%$ lighter and $4 \%$ smaller [49]. Recently, General Electric has released megawatt level photovoltaic (PV) inverter utilizing SiC MOSFETs with CEC efficiency approaching 99\% [14]. Also note that more and more all $\mathrm{SiC}$ based power modules with increased current capability become commercially available, which will accelerate the adoption of $\mathrm{SiC}$ active devices in commercial products.

\section{3) Topology Simplification with High Voltage (HV) SiC Devices}

Limited by the voltage and frequency capabilities of $\mathrm{Si}$ devices, today's MV drives typically employ complicated multi-level topologies, such as three-level NPC topologies and cascaded H-bridge (CHB) topologies. High voltage and fast switching $\mathrm{SiC}$ devices offer an opportunity to achieve the same functions and performance with the simple twolevel voltage source converter. The number of active and passive components can be reduced. Therefore, complexity of converter design and operation is reduced, resulting in higher density, higher reliability and lower cost.

It was investigated that in MV motor drive application, high voltage $\mathrm{SiC}$ based two-level voltage source inverter exhibited the most promising performance as compared to $\mathrm{Si}, \mathrm{Si} / \mathrm{SiC}$ hybrid, all $\mathrm{SiC}$ based three-level NPC inverter, with the fewest number of components, lowest power loss, and smallest cooling system size/weight [83]. Recently the U.S. Department of Energy (DOE) initiated the Next Generation Electric Machines program. One of the main research and development efforts is to leverage recent $\mathrm{SiC}$ technology advancements in power electronics of MV megawatt (MW) drive systems for a wide variety of critical energy applications. Using high voltage $\mathrm{SiC}$ power semiconductor devices with simplified topology is one of the promising approaches to improve the density by the factor of 3 along with $50 \%$ reduction of loss for MV MW level power electronics converter [84]. Also, DOE targets the Technology Readiness Levels (TRL) will improve to 6 or beyond at the end of the program as compared to current TRL of 4 or below. Therefore, it can be expected the commercial product based on this technology will be ready in the near future. Furthermore, SiC device manufacturers have taken the initiative to develop high voltage large current $\mathrm{SiC}$ power module to support this effort. It is reported that $10 \mathrm{kV} / 240 \mathrm{~A}$ $\mathrm{SiC}$ MOSFETs based phase-leg power modules, and $6.5 \mathrm{kV} /$ $200 \mathrm{~A}$ SiC JFETs based phase-leg power modules have been developing with some promising demonstrations [66], [67].

\section{B. System Level Benefits}

In addition to power converters themselves, $\mathrm{SiC}$ devices also bring benefits at system level as a result of the high switching frequency capability and high control bandwidth, especially for the system where the high controllability is required. One example focusing on the distribution energy resource interface converters in microgrid system is presented here.

A microgrid may contain a number of distribution energy resources (DER), such as photovoltaic (PV), battery energy storage system (BESS), wind turbine generator, etc. Considering the characteristics are similar for gridinterface power electronics converters for different kinds of DER, a PV system and a BESS system are selected as representatives of DERs in this case study. Fig. 3 illustrates the configuration of the $1 \mathrm{MW}$ microgrid with the DER interface converters highlighted. In the following analysis, comparisons based on simulation between Si based interface converter with $3 \mathrm{kHz}$ switching frequency and $\mathrm{SiC}$ based one with $10 \mathrm{kHz}$ switching frequency are conducted from different aspects.

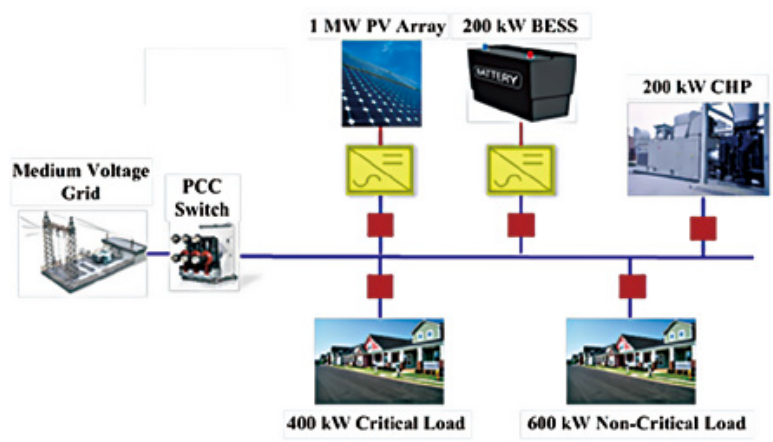

Fig. 3. Configuration of microgrid system.

\section{1) Power Quality Improvement}

The growing use of electronic equipment produces a large amount of harmonics in the power distribution systems because of non-sinusoidal currents consumed by nonlinear loads. Traditionally, harmonic distortion in power distribution systems can be suppressed using passive and/ or active filters. Thanks to the high voltage high frequency $\mathrm{SiC}$ devices, the harmonic compensation function can be integrated into the $\mathrm{SiC}$ based DER interface converter. In other words, no dedicated filters are needed.

A simulation study was carried out based on configuration in Fig. 3 at $1 \mathrm{MW}$ power rating with six-pulse uncontrolled rectifier as the representative of the non-linear load. It shows that to maintain the Total Demand Distortion (TDD) of the Point of Common Coupling (PCC) on grid side smaller than $5 \%$, in $\mathrm{Si}$ based solution with $3 \mathrm{kHz}$ switching frequency, a dedicated active power filter (APF) is required, then the total current rating of the power converter equals the sum of the rms value of the PV output current and the APF output current. In $\mathrm{SiC}$ version with $10 \mathrm{kHz}$ switching frequency, the total current rating is almost the same as the rms value of the 
PV output current. The simulation results show that in a wide range of grid impedance from 0.01 p.u. to 0.15 p.u., Si version design needs an extra $150 \mathrm{kVA}(15 \%$ more $)$ converter for APF while the impact on $\mathrm{SiC}$ based converter rating is minimal $(\sim 1 \%)$. By eliminating the dedicated active filters, the $\mathrm{SiC}$ based approach saves about $14 \%$ converter rating.

\section{2) System Stability Enhancement}

Multiple renewable energy and energy storage interface converters in microgrids, connected to relatively weak grids, can lead to harmonic resonance and stability issues [85], [86]. SiC-based converters, with their switching frequency and high control bandwidth, can help damp the resonance/ oscillation and enhance stability.

To investigate the benefits of SiC-based interface converters on the system stability, two cases based on $\mathrm{Si}$ and $\mathrm{SiC}$ are set up and compared. Specifically, Si based interface converter has lower switching frequency $(3 \mathrm{kHz})$ and limited current control bandwidth $(300 \mathrm{~Hz})$ while $\mathrm{SiC}$ based converter is with higher switching frequency $(10 \mathrm{kHz})$ and current control bandwidth $(1 \mathrm{kHz})$. As shown in Fig. 4, under the weak grid condition where the grid impedance in 0.1 p.u., integration of Si based interface converter into the microgrid system becomes unstable with the resonance of about $1 \mathrm{kHz}$ while $\mathrm{SiC}$ based interface converter is able to ensure the system stability. Due to the advantage of a higher switching frequency and a smaller time delay in the control loop, the $\mathrm{SiC}$-based converter possesses a non-passive range in the higher frequency range, compared with that of the Si-based converter. Therefore, when connecting to a weak grid, the SiC-based converter has a smaller destabilization effect on the system stability, compared with the Si-based converter. In other words, weak grids with SiC-based converters have better stability than those with Si-based converters.

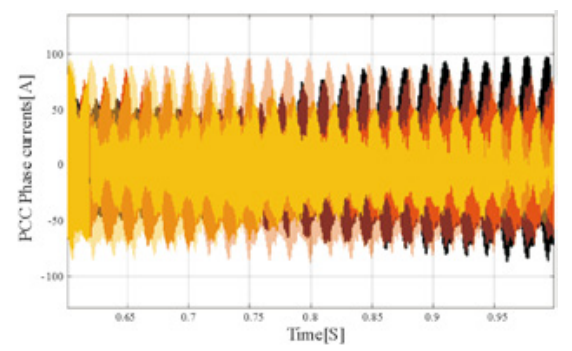

(a) PCC phase current with Si based interface converter.

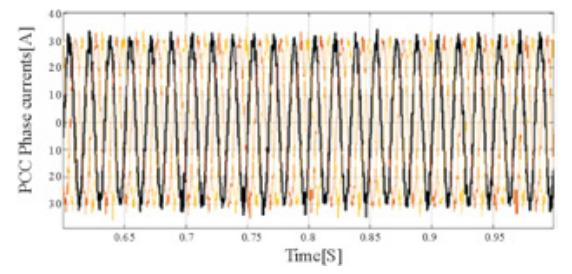

(b) PCC phase current with $\mathrm{SiC}$ based interface converter.

Fig. 4. Simulation results comparison when the grid impedance is 0.1 p.u..

\section{Enabled Emerging Applications}

$\mathrm{SiC}$ based converters, with much enhanced capability can replace or enhance conventional configurations or functions that cannot be achieved by traditional $\mathrm{Si}$ based converters with limited capability. This is also an active area of research. Three examples are highlighted here.

\section{1) High-Speed Motor Drive System}

The high switching frequency can enable high speed motor which will have higher power density and smaller footprint. The system impact of high speed motors depends on applications.

One example is for the natural high speed loads like compressors, the gearbox can be eliminated for reduced maintenance, high reliability, and potentially lower system cost. The footprint of the high-speed direct-coupled system can be only $41 \%$ of the traditional low-speed system with gearbox, and the power density can increase to 2.5 times [83]. Note that there are Si based high speed motor drives available commercially. They either involve de-rating at the high speeds or involve special complex topologies (e.g. multi-level, interleaving).

\section{2) High Performance Solid-state Transformer}

Another attractive application of $\mathrm{SiC}$ devices is in the replacement of bulky line-frequency 50 or $60 \mathrm{~Hz}$ transformers with solid-state alternatives based on high frequency link transformers especially in MV applications, such as distribution grid, shipboard power systems, high-speed train traction drives [87]. A significant size and weight reduction can be achieved for the transformer since the magnetic core size is, as a first order approximation, inversely proportional to its operating frequency, as shown in Fig. 5.

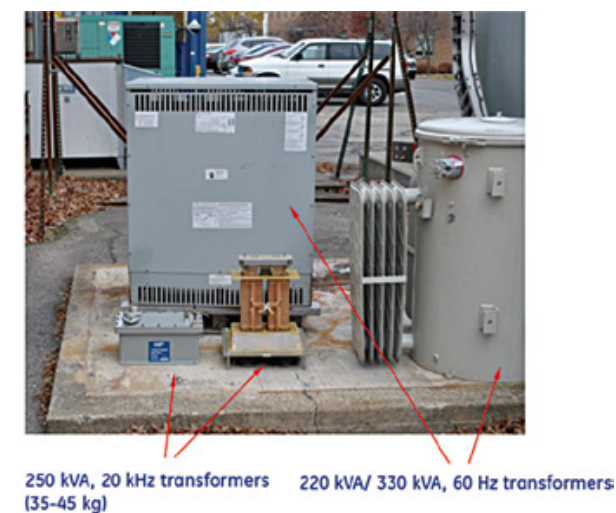

Fig. 5. High frequency vs line frequency transformers.

To realize high frequency (e.g. $20 \mathrm{kHz}$ as in Fig. 5) link for a MV transformer, it would take a large number of low voltage high frequency Si IGBT devices or converters to series, or high voltage low frequency Si IGBT devices or converters to parallel. In contrast, high voltage $\mathrm{SiC}$ MOSFETs with their faster switching speed enable power modules with decreased size and weight, and high switching frequency operation $(20-40 \mathrm{kHz})$. Fig. 6 shows the reduction in size achievable with a single high voltage $\mathrm{SiC}$ device instead of a stack of lower voltage silicon IGBTs as well as the key static and dynamic characteristics comparison. 


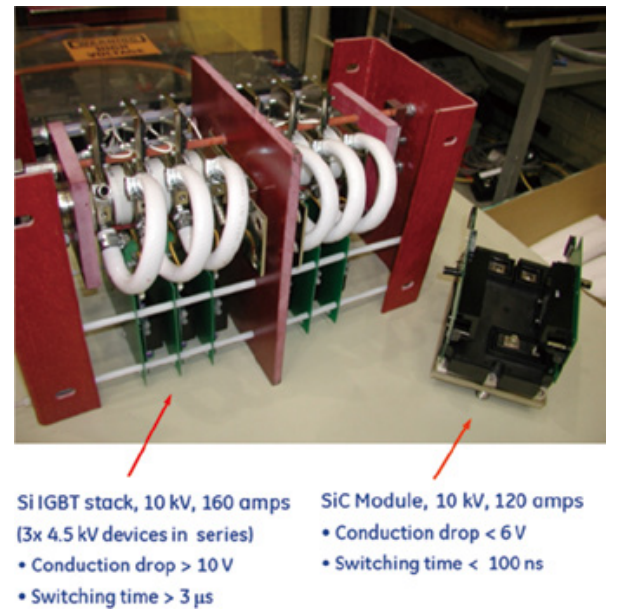

Fig. 6. SiC $10 \mathrm{kV}$ modules vs Si IGBT stack.

Fig. 7 shows a prototype SST based on 10-kV, 120-A SiC MOSFETs phase-leg power module, a 1-MW, 4160-V threephase ac to $1000-\mathrm{V}$ dc converter with a $40 \mathrm{kHz}$ isolation transformer. This unit has a weight of $900 \mathrm{~kg}$, which is approximately $10 \%$ of the $60 \mathrm{~Hz}$ transformer-rectifier unit used currently. The volume is also reduced to a third of the existing unit.

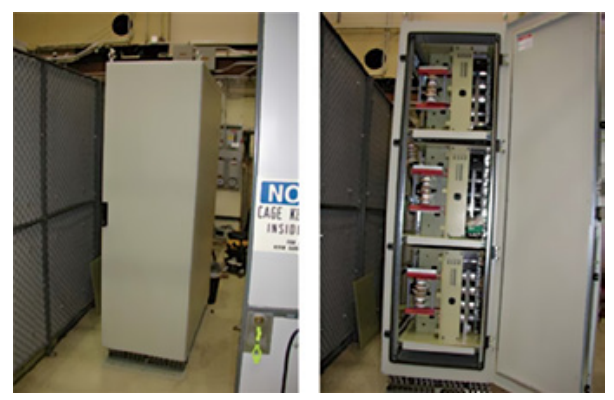

Fig. 7. Prototype $1 \mathrm{MW}, 4160-\mathrm{V}$ ac/1000-V dc converter.

\section{3) Solid-state Fault Current Limiter and Circuit Breaker}

Substitution of fuses and circuit breakers (CBs) with $\mathrm{SiC}$ based fault current limiters for short-circuit protection is another promising application. Fuses and CBs are proven and reliable protection equipment. However, fuses are single-use devices, which have to be manually replaced and cause prolonged service interruptions; CBs with high-current interrupting capabilities are bulky and expensive electromechanical systems. More importantly, electromechanical CBs are relatively slow and cannot break dc current. Furthermore, due to the increasing power demand in modern electric power system, the higher fault currents are expected. This increased fault current levels may in the future exceed the interrupting capability of existing CBs [88].

Solid-state fault current limiter (SSFCL) and solidstate circuit breaker (SSCB) have been proposed as a new device to limit and/or interrupt fault currents before their first maximum peaks are reached through fast isolating faulted sections. Similar to SSTs, SSFCLs and SSCBs can be realized by both $\mathrm{Si}$ and $\mathrm{SiC}$ devices. With higher blocking voltages, greater current densities, higher operating temperatures, and faster switching speeds, $\mathrm{SiC}$ based SSFCLs and SSCBs can achieve better protection while also have smaller size and high reliability, and eventually lower and acceptable cost. Recently, several MV SiC based SSFCLs have been designed and installed in electric power distribution systems which have successfully demonstrated their functionality and feasibility [6], [89].

\section{SiC Based Appications}

This section summarizes the applications where $\mathrm{SiC}$ power devices have been adopted or have potentials to be beneficial and commercialized. It includes but should not be limited to electric utility grid, transportation, industrial motor drive, and power supply. For each example in a given application, specifications, performance and/or benefits with employing $\mathrm{SiC}$ are highlighted. Also, the specific realization approaches (e.g. replacement of diode and/or active switch, modification of topology) are presented.

Note that $\mathrm{SiC}$ based power conversion systems and applications have been extensively investigated for years and are still active area of research. It is hardly possible to cover all $\mathrm{SiC}$ related research activities and product development. The purpose here is to present a few examples to highlight the existing and potential applications for $\mathrm{SiC}$ devices along with the benefits due to $\mathrm{SiC}$ devices. The resources summarized as follows are mainly from U.S. with some other countries included as well.

\section{A. Utility Grid}

TABLE II summarizes the selected $\mathrm{SiC}$ power converters in utility application, including renewable energy (e.g. PV, wind), distribution grid (e.g. SST), energy storage (e.g. flywheel, BESS), protection (e.g. SSFCL, SSCB), Flexible AC Transmission System (FACTS), and High Voltage Direct Current (HVDC) system.

Efficiency is a key consideration for utility application by adopting $\mathrm{SiC}$ based solution. The reduced cooling and passive requirements and the resultant cost reduction and reliability enhancement are also important. Furthermore, the fast dynamics and high control bandwidth as discussed in Section III introduces further benefits.

Also note that some equipment, such as SST, SSFCL, and SSCB, are not limited to utility application but can be leveraged to any applications with electric power system, such as shipboard, electrified train.

\section{B. Transportation}

TABLE III summarizes several examples of $\mathrm{SiC}$ based transportation application, including hybrid electric vehicle (HEV) and electric vehicle (EV), train (including metro), more electric aircraft (MEA). Also, as discussed above, $\mathrm{SiC}$ based converter, such as SST, are being developed for shipboard and train as well. 
TABLE II

Summary of Selected SiC Power Conversion Systems in Utility Applications

\begin{tabular}{|c|c|c|c|c|}
\hline Application & $\begin{array}{l}\text { Commercial or } \\
\text { R\&D, Year }\end{array}$ & $\begin{array}{l}\text { Researcher/ } \\
\text { Developer }\end{array}$ & $\begin{array}{l}\text { Specifications, Performance and/ } \\
\text { or Benefits by Employing SiC }\end{array}$ & Realization Approach \\
\hline PV $[16]$ & $\mathrm{R} \& \mathrm{D}, 2016$ & $\begin{array}{l}\text { Technical } \\
\text { University } \\
\text { of Denmark, } \\
\text { Denmark }\end{array}$ & $\begin{array}{l}\text { T-type inverter for Grid-Tie application, } 800 \mathrm{Vdc} \text {, } \\
\text { reduced semiconductor losses by more than } 50 \% \text {, } \\
\text { increased converter efficiency up to } 1 \% \text { at light load and } \\
\text { more than } 60 \% \text { reduction of cooling requirement with } \\
16 \mathrm{kHz} \text { switching frequency, up to } 192 \mathrm{kHz} \text { switching } \\
\text { frequency at } 1.5 \mathrm{~kW} \text { with reduced magnetic size }\end{array}$ & $\begin{array}{l}\text { Substitution of Si IGBTs with } \\
\text { SiC MOSFETs }\end{array}$ \\
\hline PV [15] & $\mathrm{R} \& \mathrm{D}, 2014$ & $\begin{array}{l}\text { Infineon } \\
\text { Technologies, } \\
\text { Germany }\end{array}$ & $\begin{array}{l}17 \mathrm{~kW}, 650 \mathrm{Vdc} \text {, reduced semiconductor losses in the } \\
\text { converter, which maintains electrical performance at } \\
\text { high switching frequency and then lowering costs. In the } \\
\text { end, achieve up to } 20 \% \text { system cost reduction }\end{array}$ & $\begin{array}{l}\text { Substitution of Si IGBTs } \\
\text { with SiC JFETs \& topology } \\
\text { simplification ( } 3 \text { level to } 2 \\
\text { level) }\end{array}$ \\
\hline PV [14] & $\begin{array}{l}\text { Commercial } \\
\text { Product, } 2016\end{array}$ & $\begin{array}{l}\text { General Electric, } \\
\text { U.S. }\end{array}$ & MW class, $1500 \mathrm{Vdc}, 99 \%$ CEC efficiency & $\begin{array}{l}\text { Substitution of Si IGBTs with } \\
\text { SiC MOSFETs }\end{array}$ \\
\hline PV $[13]$ & $\mathrm{R} \& \mathrm{D}, 2016$ & $\begin{array}{l}\text { Florida State } \\
\text { University, U.S. }\end{array}$ & $\begin{array}{l}\text { T-type inverter, } 50 \mathrm{~kW}, 50 \mathrm{kHz} \text { switching frequency, } \\
\text { natural convection, } 99.1 \% \text { peak efficiency, } 22.7 \mathrm{~W} / \mathrm{in} 3 \\
\text { volumetric power density, } 2.5 \mathrm{~kW} / \mathrm{kg} \text { specific power, } \\
\text { improved power density by a factor of } 3 \mathrm{vs} \mathrm{Si} \mathrm{based} \\
\text { state-of-the-art product }\end{array}$ & $\begin{array}{l}\text { Substitution of Si IGBTs with } \\
\text { SiC MOSFETs }\end{array}$ \\
\hline Wind [12] & R\&D, 2006 & $\begin{array}{l}\text { Peregrine Power } \\
\text { LLC, U.S. }\end{array}$ & $\begin{array}{l}\text { Multi-megawatt rating, } 30 \%-50 \% \text { switching loss } \\
\text { reduction and } 15 \%-25 \% \text { total los reduction by } \\
\text { Substitution of Si diode with } \mathrm{SiC} \mathrm{SBD} \text {, leading to } 0.4 \% \\
\text { increase in average efficiency and energy production. } \\
\text { Expected to employ } \mathrm{SiC} \text { active devices for wind turbine } \\
\text { with nominal voltage from } 690 \text { to } 4,160 \mathrm{Vac}\end{array}$ & $\begin{array}{l}\text { Substitution of Si diodes with } \\
\text { SiC Schottky diodes }\end{array}$ \\
\hline Wind [11] & $\mathrm{R} \& \mathrm{D}, 2011$ & $\begin{array}{l}\text { Tuskegee } \\
\text { Univ. / Univ. of } \\
\text { Tennessee, U.S. }\end{array}$ & $\begin{array}{l}1.5 \mathrm{MW}, 690 \mathrm{Vac}, 1.1 \mathrm{kVdc} \text {, improved wind system } \\
\text { power conversion efficiency and reduce the system size } \\
\text { and cost due to increasing the switching frequency from } \\
3 \mathrm{kHz} \text { by Si IGBT to } 50 \mathrm{kHz} \text { by SiC MOSFET with high } \\
\text { temperature properties }\end{array}$ & $\begin{array}{l}\text { Substitution of Si IGBTs with } \\
\text { SiC MOSFETs }\end{array}$ \\
\hline SST $[10]$ & $\mathrm{R} \& \mathrm{D}, 2011$ & $\begin{array}{l}\text { Cree, GE, } \\
\text { Powerex Inc., } \\
\text { NIST, U.S. }\end{array}$ & $\begin{array}{l}10 \mathrm{kV} \mathrm{SiC} \mathrm{MOSFETs} \mathrm{with} \mathrm{low} \mathrm{switching} \mathrm{and} \mathrm{conduction} \\
\text { losses leads to } 75 \% \text { reduction in weight, } 50 \% \text { reduction } \\
\text { in size, } 97.1 \% \text { efficiency, and cooler operation. Note that } \\
\text { in addition to utility, SST can be used in other power } \\
\text { distribution systems, such as shipboard power system, } \\
\text { railway traction system }\end{array}$ & SiC enabled new application \\
\hline SST [9] & $\mathrm{R} \& \mathrm{D}, 2015$ & $\begin{array}{l}\text { North Carolina } \\
\text { State Univ., U.S. }\end{array}$ & $\begin{array}{l}13.8 \mathrm{kV} \text { to } 480 \mathrm{~V} \text { grid-interfaced three-phase SST using } \\
15 \mathrm{kV} \mathrm{SiC} \mathrm{n-IGBT,} 96.75 \% \text { efficiency for transformer- } \\
\text { less intelligent power substation }\end{array}$ & SiC enabled new application \\
\hline Flywheel ESS [8] & $\mathrm{R} \& \mathrm{D}, 2015$ & $\begin{array}{l}\text { Sanken Electric } \\
\text { Co. / Nagaoka } \\
\text { Power Elec. Co., } \\
\text { Japan }\end{array}$ & $\begin{array}{l}\text { Matrix converter, } 5 \mathrm{~kW}, 200 \mathrm{Vac}, 25 \mathrm{kHz} \text { switching } \\
\text { frequency, } 98 \% \text { efficiency, increased lifetime over } 20 \\
\text { years, reduced maintenance time and cost by eliminating } \\
\text { low lifetime components in the system. }\end{array}$ & $\begin{array}{l}\text { Substitution of Si devices with } \\
\text { SiC MOSFETs \& topology } \\
\text { modification }\end{array}$ \\
\hline Battery ESS [7] & R\&D, 2016 & $\begin{array}{l}\text { Univ. of } \\
\text { Cambridge/ Univ. } \\
\text { of Warwick, UK }\end{array}$ & $\begin{array}{l}1-10 \mathrm{~kW} \text { converter application range where battery } \\
\text { storage is applied, } 50.8 \% \text { loss reduction at } 20 \mathrm{kHz} \text { by } \\
\text { SiC MOSFET vs Si IGBT, } 98.8 \% \text { efficiency at } 40 \mathrm{kHz} \text { by } \\
\text { using SiC MOSFETs and } 98.6 \% \text { by using SiC BJT }\end{array}$ & $\begin{array}{l}\text { Substitution of Si IGBTs with } \\
\text { SiC active devices }\end{array}$ \\
\hline SSFCL [6] & R\&D, 2014 & $\begin{array}{l}\text { Univ. of Arkansas, } \\
\text { U.S. }\end{array}$ & $\begin{array}{l}4.16 \mathrm{kV} \mathrm{SiC} \text { super gate turn-off thyristor based solid state } \\
\text { fault current limiter successfully blocked an overcurrent } \\
\text { within } 40 \mu \mathrm{s} \text {. }\end{array}$ & SiC enabled new application \\
\hline SSCB [5] & $\mathrm{R} \& \mathrm{D}, 2016$ & Wolfspeed, U.S. & $\begin{array}{l}\text { SiC module based solid state circuit breaker handles a } \\
250 \mathrm{~A} \text { fault in 10us and a } 450 \mathrm{~A} \text { fault in } 70 \text { us on a } 270 \\
\text { VDC bus, reduced space and weight, higher power } \\
\text { density, longer lifetime due to absence of mechanical } \\
\text { parts }\end{array}$ & SiC enabled new application \\
\hline FACTS [4] & R\&D, 2014 & $\begin{array}{l}\text { Central } \\
\text { Queensland } \\
\text { University, } \\
\text { Australia }\end{array}$ & $\begin{array}{l}30 \mathrm{kVA} \text { dSTATCOM, reduced power loss, increased } \\
\text { allowable environment temperature by using } \mathrm{SiC} \\
\text { devices, fast switching frequency can lower required DC } \\
\text { bus capacitance, which is beneficial to cost and failure } \\
\text { rate in power conversion system }\end{array}$ & $\begin{array}{l}\text { Substitution of Si devices with } \\
\text { SiC active devices }\end{array}$ \\
\hline HVDC [3] & R\&D, 2015 & $\begin{array}{l}\text { SuperGrid } \\
\text { Institute / } \\
\text { University of } \\
\text { Toulouse, France }\end{array}$ & $\begin{array}{l}\text { Insulated dc-dc converter for off-shore wind application, } \\
735 \mathrm{kVA}, 20 \mathrm{kVdc} \text { output voltage, } 10 \mathrm{kHz} \text { switching } \\
\text { frequency, } 99 \% \text { efficiency by using } 10 \mathrm{kV} \mathrm{SiC} \mathrm{MOSFET}\end{array}$ & Topology modification \\
\hline
\end{tabular}


TABLE III

Summary of Selected SiC Power Conversion Systems in Transportation Applications

\begin{tabular}{|c|c|c|c|c|}
\hline Application & $\begin{array}{l}\text { Commercial or } \\
\text { R\&D, Year }\end{array}$ & Researcher/ Developer & $\begin{array}{l}\text { Specifications, Performance and/or Benefits by } \\
\text { Employing } \mathrm{SiC}\end{array}$ & Realization Approach \\
\hline $\mathrm{HEV}[35]$ & $\mathrm{R} \& \mathrm{D}, 2011$ & Univ. of Tennessee, U.S. & $\begin{array}{l}\text { Inverter efficiency up from } 74.3 \% \text { to } 89.1 \% \text {, } \\
\text { system efficiency up from } 32.9 \% \text { to } 37.3 \%\end{array}$ & $\begin{array}{l}\text { Substitution of Si IGBTs } \\
\text { with SiC JFETs }\end{array}$ \\
\hline HEV [33] & $\begin{array}{l}\text { Commercial product, } \\
2014\end{array}$ & Toyota, Japan & $5 \%$ higher fuel efficiency, $80 \%$ reduction in size & $\begin{array}{l}\text { Substitution of Si with } \\
\text { SiC devices }\end{array}$ \\
\hline $\mathrm{HEV}[31]$ & $\mathrm{R} \& \mathrm{D}, 2013$ & Nissan research center, Japan & $\begin{array}{l}25 \mathrm{kVA}, 600 \mathrm{Vdc}, 8 \mathrm{kHz} \text { switching frequency, } \\
70 \mathrm{kVA} / \mathrm{L} \text { air-cooled inverter module, } 98.8 \% \\
\text { efficiency with } 15 \mathrm{~kW} \text {-class induction motor }\end{array}$ & $\begin{array}{l}\text { Substitution of Si devices } \\
\text { with SiC JFETs }\end{array}$ \\
\hline $\mathrm{HEV}[27]$ & Commercial product & $\begin{array}{l}\text { McLaren Technology } \\
\text { Centre, UK }\end{array}$ & $\begin{array}{l}\text { Motor control unit }(\mathrm{MCU})-500 \text { used in McLaren } \\
\mathrm{P} 1 \mathrm{road} \text { car, } 120 \mathrm{~kW},>20 \mathrm{~kW} / \mathrm{kg} \text { specific power }\end{array}$ & $\begin{array}{l}\text { Substitution of Si devices } \\
\text { with SiC MOSFETs }\end{array}$ \\
\hline $\mathrm{HEV}[32]$ & R\&D, 2016 & $\begin{array}{l}\text { North Carolina State Univ., } \\
\text { U.S. }\end{array}$ & $\begin{array}{l}\text { Up to } 55 \mathrm{~kW}, 2 \% \text { higher efficiency, } 12.1 \mathrm{~kW} / \mathrm{L} \\
\text { power density }\end{array}$ & $\begin{array}{l}\text { Substitution of Si devices } \\
\text { with SiC MOSFETs }\end{array}$ \\
\hline HEV [30] & R\&D, 2008 & $\begin{array}{l}\text { National Technical Univ. } \\
\text { of Athens, Greece, Lund } \\
\text { Institute of Tech., Sweden }\end{array}$ & $\begin{array}{l}5 \mathrm{~kW} \text {, Efficiency higher than } 98 \% \text {, smaller size, } \\
\text { less cooling requirement, } 130^{\circ} \mathrm{C} \text { operation }\end{array}$ & $\begin{array}{l}\text { Substitution of Si devices } \\
\text { with SiC BJT }\end{array}$ \\
\hline $\mathrm{EV}[29]$ & $\begin{array}{l}\text { Commercial product, } \\
2014\end{array}$ & Mitsubishi Electric, Japan & $60 \mathrm{~kW} / 14.1 \mathrm{~L}$ & $\begin{array}{l}\text { Substitution of Si with } \\
\text { SiC devices }\end{array}$ \\
\hline $\mathrm{EV}[26]$ & $\mathrm{R} \& \mathrm{D}, 2016$ & Siemens / Porsche, Germany & $\begin{array}{l}40 \mathrm{kHz} \text { switching frequency, } 140 \mathrm{~kW}, 450 \sim 850 \\
\mathrm{Vdc} \text {, High switching frequency/lower loss, } \\
\text { smaller size }\end{array}$ & $\begin{array}{l}\text { Substitution of Si devices } \\
\text { with SiC MOSFETs }\end{array}$ \\
\hline EV [25] & R\&D, 2014 & University of Padova, Italy & $\begin{array}{l}80 \mathrm{~kW}, 20 \mathrm{kHz} \text { switching frequency, } 100 \mathrm{~kJ} \\
\text { energy saving per driving cycle ( } 5 \% \text { longer } \\
\text { range) }\end{array}$ & $\begin{array}{l}\text { Substitution of Si IGBTs } \\
\text { with SiC MOSFETs }\end{array}$ \\
\hline EV [24] & R\&D, 2014 & $\begin{array}{l}\text { Fraunhofer IISB, Germany, } \\
\text { Swerea IVF, Sweden }\end{array}$ & $\begin{array}{l}290 \mathrm{kVA}, 800 \mathrm{Vdc} \text {, up to } 175^{\circ} \mathrm{C} \text { operating } \\
\text { temperature, smaller size }\end{array}$ & $\begin{array}{l}\text { Substitution of Si IGBTs } \\
\text { with SiC BJTs }\end{array}$ \\
\hline EV [23] & R\&D, 2014 & $\begin{array}{l}\text { Leibniz University of } \\
\text { Hanover, Germany }\end{array}$ & $\begin{array}{l}10 \mathrm{kHz} \text { switching frequency, up to } 70 \% \text { loss } \\
\text { reduction in energy loss and } 66 \% \text { reduction in } \\
\text { chip area }\end{array}$ & $\begin{array}{l}\text { Substitution of Si devices } \\
\text { with } \mathrm{SiC} \text { devices. }\end{array}$ \\
\hline $\mathrm{EV}[28]$ & Commercial product & $\begin{array}{l}\text { Venturi Automobiles, } \\
\text { Monaco McLaren, UK }\end{array}$ & $\begin{array}{l}\text { Venturi VM200, up to } 200 \mathrm{~kW} \text {, over } 19,000 \mathrm{rpm} \\
\text { and over } 150 \mathrm{Nm} \text { torque peak performance, } \\
\text { more competitive to win the FIA Formula-E } \\
\text { Championship }\end{array}$ & $\begin{array}{l}\text { Substitution of Si devices } \\
\text { with SiC devices. }\end{array}$ \\
\hline $\begin{array}{l}\text { Metro [17], } \\
{[18]}\end{array}$ & $\begin{array}{l}\text { Commercial product, } \\
2013\end{array}$ & Mitsubishi Electric, Japan & $\begin{array}{l}140 \mathrm{kVA}, 600 \mathrm{Vdc} \text {, Natural air-cooling, installed } \\
\text { in Tokyo Metro's Tozai Line subway, } 30 \% \\
\text { less power loss, } 20 \% \text { smaller, } 15 \% \text { lighter, } \\
\text { reduced transformer noise by } 4 \mathrm{~dB} \text { due to a } 35 \% \\
\text { improvement in the distortion rate of output } \\
\text { voltage waveforms, } 51 \% \text { energy regeneration } \\
\text { compared to } 22.7 \% \text { of Si based }\end{array}$ & $\begin{array}{l}\text { Substitution of Si IGBTs } \\
\text { with } \mathrm{SiC} \text { devices }\end{array}$ \\
\hline MEA [22] & R\&D, 2007 & ETH Zurich, Switzerland & $\begin{array}{l}1.5 \mathrm{~kW} \text { continuous output power, } 5 \mathrm{~kW} \text { peak } \\
\text { output power, } 115 \mathrm{Vrms} \text { input voltage, } 94 \% \\
\text { efficiency, } 1.5 \mathrm{~kW} / \mathrm{L} \text { volumetric power density }\end{array}$ & $\begin{array}{l}\text { Substitution of Si devices } \\
\text { with SiC JFET in cascode } \\
\text { structure }\end{array}$ \\
\hline MEA [21] & R\&D, 2016 & $\begin{array}{l}\text { Microsemi, Ireland } \\
\text { University of Nottingham, } \\
\text { UK }\end{array}$ & $\begin{array}{l}5 \mathrm{kVA}, 540 \mathrm{Vdc}, 40{ }^{\circ} \mathrm{C} \text { lower skin temperature, } \\
\text { continued } \mathrm{SiC} \text { based module operation for } \\
150,000 \text { flight hours }\end{array}$ & $\begin{array}{l}\text { Substitution of Si IGBTs } \\
\text { with SiC MOSFETs }\end{array}$ \\
\hline MEA [19] & $\mathrm{R} \& \mathrm{D}, 2010$ & Virginia Tech, Boeing, U.S. & $\begin{array}{l}10 \mathrm{~kW}, 70 \mathrm{kHz} \text { switching frequency, } 3.59 \mathrm{~kW} / \\
\mathrm{kg} \text { specific power, } 3.03 \mathrm{~kW} / \mathrm{L} \text { volumetric power } \\
\text { density, } 95.4 \% \text { efficiency at } 5.1 \mathrm{~kW} \text { load }\end{array}$ & $\begin{array}{l}\text { Substitution of Si devices } \\
\text { with SiC JFETs }\end{array}$ \\
\hline MEA [20] & $\mathrm{R} \& \mathrm{D}, 2010$ & Virginia Tech, Boeing, U.S. & $\begin{array}{l}15 \mathrm{~kW}, 650 \mathrm{Vdc}, 70 \mathrm{kHz} \text { switching frequency, } \\
6.3 \mathrm{~kW} / \mathrm{L} \text { volumetric power density, } 2.78 \mathrm{~kW} / \\
\text { lb specific power, up to } 250{ }^{\circ} \mathrm{C} \text { device operating } \\
\text { temperature }\end{array}$ & $\begin{array}{l}\text { Substitution of Si devices } \\
\text { with SiC JFETs }\end{array}$ \\
\hline
\end{tabular}

In general, high density is a key goal for the $\mathrm{SiC}$ based converter in transportation application. High temperature capability may also be important in this application since the ambient temperature of transportation system is usually higher than room temperature. Also, by elevating the device junction operating temperature, less cooling requirement and high density can be realized.

\section{Industrial Motor Drive}

TABLE IV summarizes the selected $\mathrm{SiC}$ power converters in industrial motor drive application.

In general, high efficiency, low cost, as well as small volume/footprint are main objectives for $\mathrm{SiC}$ based motor drives. For special cases, such as compressors applied in oil 
TABLE IV

Summary of Selected SiC Power Conversion Systems in Industrial Motor Drive Applications

\begin{tabular}{|c|c|c|c|c|}
\hline Application & $\begin{array}{l}\text { Commercial or } \\
\text { R\&D, Year }\end{array}$ & Researcher/ Developer & $\begin{array}{l}\text { Specifications, Performance and/or Benefits } \\
\text { by Employing } \mathrm{SiC}\end{array}$ & Realization Approach \\
\hline MV Drive [36] & R\&D, 2016 & $\begin{array}{l}\text { North Carolina State Univ., } \\
\text { U.S. }\end{array}$ & 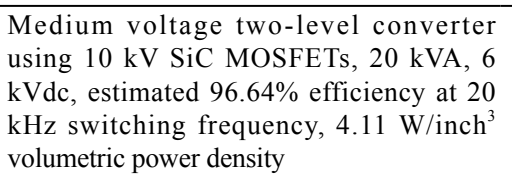 & $\begin{array}{l}\text { Topology Simplification } \\
\text { with } 10 \mathrm{kV} \mathrm{SiC} \mathrm{MOSFETs}\end{array}$ \\
\hline Motor Drive [39] & $\mathrm{R} \& \mathrm{D}, 2015$ & Danfoss Drives, Denmark & $\begin{array}{l}18.5 \mathrm{~kW}, 16 \mathrm{kHz} \text { switching frequency, } 3 \% \\
\text { efficiency increase across wide power range } \\
(6-17 \mathrm{~kW}) \text { over Si IGBTs }\end{array}$ & $\begin{array}{l}\text { Substitution of Si IGBTs } \\
\text { with SiC MOSFETs and } \\
\text { SBDs }\end{array}$ \\
\hline Motor Drive [38] & R\&D, 2007 & $\begin{array}{l}\text { Cree/ North Carolina State } \\
\text { Univ., U.S. }\end{array}$ & $\begin{array}{l}60 \mathrm{~kW}, 600 \mathrm{Vdc}, 10 \mathrm{kHz} \text { switching } \\
\text { frequency, } 68 \% \text { reduction in conduction } \\
\text { loss, } 78 \% \text { reduction in switching loss, } 99.1 \% \\
\text { efficiency with } 2 \% \text { overall increase, and } \\
75 \% \text { size reduction of heat sink by using } \mathrm{SiC} \\
\text { vs } \mathrm{Si}\end{array}$ & $\begin{array}{l}\text { Substitution of Si IGBTs } \\
\text { with SiC MOSFETs }\end{array}$ \\
\hline Motor Drive [37] & R\&D, 2014 & $\begin{array}{l}\text { KTH Royal Institute of } \\
\text { Technology, Sweden }\end{array}$ & $\begin{array}{l}312 \mathrm{kVA}, 550 \mathrm{Vdc}, 20 \mathrm{kHz} \text { switching } \\
\text { frequency } 99.3 \% \text { efficiency over entire load } \\
\text { range }\end{array}$ & $\begin{array}{l}\text { Substitution of Si IGBTs } \\
\text { with SiC MOSFETs }\end{array}$ \\
\hline
\end{tabular}

and gas industry, high temperature capability is also critical. Moreover, compared with low voltage motor drives, medium voltage application is more suitable to fully utilize the advantages of $\mathrm{SiC}$ devices, especially with the consideration of integrating high speed medium voltage motors. Then, the high voltage high frequency $\mathrm{SiC}$ devices offer a unique opportunity to achieve highly efficient ultra-dense medium voltage integrated motor drive system with relatively simple topology and control.

\section{Power Supply}

TABLE V summarizes several examples of $\mathrm{SiC}$ based power converters for power supply, including data center power system, battery charger, and power factor correction (PFC).

In general, efficiency and volume/weight are the main focuses for $\mathrm{SiC}$ based power supply. More soft switching topologies with hundreds of $\mathrm{kHz}$ up to $\mathrm{MHz}$ switching frequency can be observed in this application. As a result, the passive need is significantly reduced, and the small size along with high efficiency can be achieved.

\section{Challenges for SiC Based Power Conversion SYSTEM}

Superior characteristics of $\mathrm{SiC}$ devices promise to significantly improve today's power conversion system. In the meanwhile, these small and fast devices also pose new design challenges. Special considerations must be given to the converter design with $\mathrm{SiC}$ devices in order to utilize them effectively and reliably. The $\mathrm{SiC}$ based converter design is still an active area for research. Several key topics are highlighted here.

\section{A. Power Module and Packaging}

Packaging device dies into power modules involve electrical, thermal, and mechanical design. The key considerations for $\mathrm{SiC}$ based power module packaging are summarized here.

Parasitic minimization: In general, parasitic electrical parameters involved in the switching loop can be categorized as either power device related internal parasitics or interconnection related external parasitics. The internal parasitics include gate-source capacitance, drain-source capacitance, Miller capacitance, and internal gate resistance; the external parasitics mainly include parasitic inductances, such as gate loop inductance, power loop inductance, and common source inductance. All these parasitics can significantly impact the switching performance of power devices, especially for the fast switching SiC devices [90], [91].

For the device module design, we have to accept the internal parasitics, and try to avoid adding extra parasitics to these parameters externally. At the same time, interconnection related external parasitics should be minimized. Some of the effective parasitic minimization techniques include magnetic field cancellation technique and P-cell and N-cell concept [92], [93].

Also, there is a trend to utilize $3 \mathrm{D}$ packaging technique to further reduce the power loop inductance inside the module [94]-[97]. With 3D designs, the commutation loop area can be effectively reduced by restricting the commutation loop in the thickness level of the device. Some existing designs revealed significant reductions of power loop inductance due to package [94]-[97].

High temperature packaging: High temperature operation of power modules reduces the cost of power electronics systems through less semiconductor use and/or lower cooling need. As SiC power devices offer higher temperature capability, high temperature packaging becomes critical. New materials and optimized thermo-mechanical design are necessary to prevent the accelerated degradation of the power modules due to high temperature or temperature excursion [98]. The high temperature technologies cover almost all aspects of the packaging: die attach, substrate, 
TABLE V

Summary of Selected SiC Power Conversion Systems in Power Supply Applications

\begin{tabular}{|c|c|c|c|c|}
\hline Application & $\begin{array}{l}\text { Commercial or } \\
\text { R\&D, Year }\end{array}$ & Researcher/ Developer & $\begin{array}{l}\text { Specifications, Performance and/or Benefits by } \\
\text { Employing } \mathrm{SiC}\end{array}$ & $\begin{array}{l}\text { Realization } \\
\text { Approach }\end{array}$ \\
\hline Data Center [49] & $\mathrm{R} \& \mathrm{D}, 2012$ & Univ. of Tennessee, U.S. & $\begin{array}{l}\text { Three-phase buck rectifier, } 7.5 \mathrm{~kW}, 400 \mathrm{Vdc}, 28 \\
\mathrm{kHz} \text { switching frequency, } 98.54 \% \text { efficiency, } \\
>70 \% \text { more efficient than Si IGBTs, } 10 \% \text { lighter } \\
\text { and } 4 \% \text { smaller than } \mathrm{Si}\end{array}$ & $\begin{array}{l}\text { Substitution of Si } \\
\text { IGBTs with } \mathrm{SiC} \\
\text { MOSFETs and } \\
\text { SBDs }\end{array}$ \\
\hline Data Center [43] & R\&D, 2016 & $\begin{array}{l}\text { ETH Zuric / ABB } \\
\text { Switzerland }\end{array}$ & $\begin{array}{l}\text { Three-phase buck-type rectifier, } 8 \mathrm{~kW}, 380 \mathrm{Vdc} \text {, } \\
27 \mathrm{kHz} \text { switching frequency, } 99 \% \text { efficiency, } 4 \\
\mathrm{~kW} / \mathrm{dm}^{3} \text { volumetric power density }\end{array}$ & $\begin{array}{l}\text { Substitution of } \mathrm{Si} \\
\text { devices with } \mathrm{SiC} \\
\text { MOSFETs }\end{array}$ \\
\hline Battery Charger [48] & R\&D, 2006 & $\begin{array}{l}\text { Univ. of Tennessee / Oak } \\
\text { Ridge National Lab, U.S. }\end{array}$ & $\begin{array}{l}\text { Utility interface for battery system, three-phase } \\
\text { voltage source inverter, } 3.1 \% \text { efficiency increase } \\
\text { during discharging vs } \mathrm{Si} ; 5.4 \% \text { efficiency increase } \\
\text { during charging vs } \mathrm{Si}\end{array}$ & $\begin{array}{l}\text { Substitution of Si } \\
\text { IGBTs with SiC } \\
\text { JFETs and SBDs }\end{array}$ \\
\hline Battery Charger [45] & $\begin{array}{l}\text { Near commercially } \\
\text { available, } 2016\end{array}$ & ABB Switzerland & $\begin{array}{l}\text { Train application, } 10 \times \text { smaller }(1 \mathrm{~kW} / \text { liter }) \text {, } \\
80 \% \text { weight reduction }(1 \mathrm{~kW} / \mathrm{kg}) \text {, more efficient } \\
\text { compared to previous generations }\end{array}$ & $\begin{array}{l}\text { Substitution of } \mathrm{Si} \\
\text { devices with } \mathrm{SiC} \\
\text { active devices }\end{array}$ \\
\hline Battery Charger [44] & $\mathrm{R} \& \mathrm{D}, 2014$ & $\begin{array}{l}\text { Global Power Electronics, } \\
\text { U.S. }\end{array}$ & $\begin{array}{l}\text { On-board vehicle battery charger, } 3.3 \mathrm{~kW}, 200 \\
\mathrm{kHz} \text { switching frequency, } 97.7 \% \text { peak efficiency } \\
\text { and } 94.7 \% \text { overall efficiency, }>1 \mathrm{~kW} / \mathrm{L} \text { volumetric } \\
\text { power density }\end{array}$ & $\begin{array}{l}\text { Substitution of Si } \\
\text { Super Junction } \\
\text { MOSFETs with SiC } \\
\text { MOSFETs }\end{array}$ \\
\hline Battery Charger [40] & R\&D, 2013 & APEI, U.S. & $\begin{array}{l}\text { On-board vehicle battery charger, phase-shifted } \\
\text { full-bridge converter, } 6.06 \mathrm{~kW}, 93.4 \% \text { efficiency } \\
\text { at } 500 \mathrm{kHz} \text { and } 96.5 \% \text { efficiency at } 200 \mathrm{kHz}, 12.0 \\
\mathrm{~kW} / \mathrm{L} \text { volumetric power density and } 9.1 \mathrm{~kW} / \mathrm{kg} \\
\text { specific power }\end{array}$ & $\begin{array}{l}\text { Substitution of } \mathrm{Si} \\
\text { devices with } \mathrm{SiC} \\
\text { active devices }\end{array}$ \\
\hline Battery Charger [42] & $\mathrm{R} \& \mathrm{D}, 2014$ & $\begin{array}{l}\text { Ikerlan Technological } \\
\text { Research Center, Spain }\end{array}$ & $\begin{array}{l}\mathrm{HEV} \text {, railway applications, } 2.5 \mathrm{~kW}, 540 \mathrm{Vdc}, 100 \\
\mathrm{kHz} \text { switching frequency, } 97.4 \% \text { global efficiency, } \\
53.54 \% \text { reduction in volume of magnetic elements, } \\
\text { reduced semiconductor operating temperature }\end{array}$ & $\begin{array}{l}\text { Substitution of } \mathrm{Si} \\
\text { devices with } \mathrm{SiC} \\
\text { MOSFETs and } \\
\text { SBDs }\end{array}$ \\
\hline Battery Charger [41] & $\mathrm{R} \& \mathrm{D}, 2016$ & $\begin{array}{l}\text { North Carolina State Univ., } \\
\text { U.S. }\end{array}$ & $\begin{array}{l}\text { EV fast charger, single phase medium voltage } \\
\text { rectifier, } 50 \mathrm{~kW} \text {, up to } 50 \mathrm{kHz},>96 \% \text { efficiency at } \\
25 \mathrm{kHz}, 0.81 \mathrm{~kW} / \mathrm{dm}^{3} \text { volumetric power density }\end{array}$ & $\begin{array}{l}\text { Substitution of Si } \\
\text { devices with } \mathrm{SiC} \\
\text { MOSFETs and } \\
\text { SBDs }\end{array}$ \\
\hline $\mathrm{PFC}[47]$ & $\mathrm{R} \& \mathrm{D}, 2003$ & Virginia Tech, U.S. & $\begin{array}{l}\text { Single-phase PFC with } \mathrm{Si} \text { CoolMOS and } \mathrm{SiC} \\
\mathrm{SBD}, 1 \mathrm{~kW}, 400 \mathrm{kHz}, 0.5 \% \text { efficiency increase at } \\
\text { full power, } 11 \mathrm{~W} / \mathrm{in}^{3} \text { volumetric power density }\end{array}$ & $\begin{array}{l}\text { Direct SiC SBD } \\
\text { placement }\end{array}$ \\
\hline PFC [46] & $\mathrm{R} \& \mathrm{D}, 2007$ & $\begin{array}{l}\text { North Carolina State Univ./ } \\
\text { CREE, U.S. }\end{array}$ & $\begin{array}{l}250 \mathrm{~W} \text {, up to } 1 \mathrm{MHz} \text { switching frequency, } 2 \% \\
\text { efficiency increase and } 33 \% \text { smaller heat sink (SiC } \\
\text { MOSFET vs. Si CoolMOS) }\end{array}$ & $\begin{array}{l}\text { Substitution of } \mathrm{Si} \\
\text { CoolMOS with } \mathrm{SiC} \\
\text { MOSFETs }\end{array}$ \\
\hline
\end{tabular}

encapsulant, and interconnection structure.

Device paralleling: Today, due to the limited current rating of single die of $\mathrm{SiC}$ device, development of $\mathrm{SiC}$ based power module with multiple dies in parallel is necessary for high power conversion system. The positive coefficient of onstate resistance of most $\mathrm{SiC}$ devices allows each paralleled device to achieve current sharing naturally. However, special attention must be paid to the dynamic current sharing during fast switching transient since the switching behavior of $\mathrm{SiC}$ devices is highly sensitive to the mismatch of parasitics in the switching loop (e.g. gate loop inductance). Accordingly, parasitics of each die should be carefully controlled via packaging and layout design to ensure good dynamic current sharing.

Capacitive coupling effect: Inside the power module, a layer of insulating material is used to separate the SiC devices from the electrically conductive baseplate. Thus, a chip to baseplate capacitance is formed [99]. Via the baseplate of power module, this coupling capacitance is paralleled with $\mathrm{SiC}$ devices, which increases their equivalent output capacitance, and worsens the switching behavior. Additionally, the chip to baseplate capacitance together with high $d v / d t$ during fast switching transient will generate large $\mathrm{CM}$ current $(37.5 \mathrm{~A}$ in three-phase voltage source inverter reported in [100]), causing severe EMI issue.

\section{B. Gate Drive}

As the interface between the micro-controller and power semiconductor devices, gate driver is a key component to achieve the optimal performance of devices in actual power converters. To fully utilize the potential benefits of $\mathrm{SiC}$ devices in actual converters, specifically the fast switching speed, the gate driver design is critical. Fig. 8 displays the components of gate driver circuits in the phaseleg configuration. Generally, gate driver mainly consists of driver integrated circuit (IC), signal isolator, and isolated power supply. 


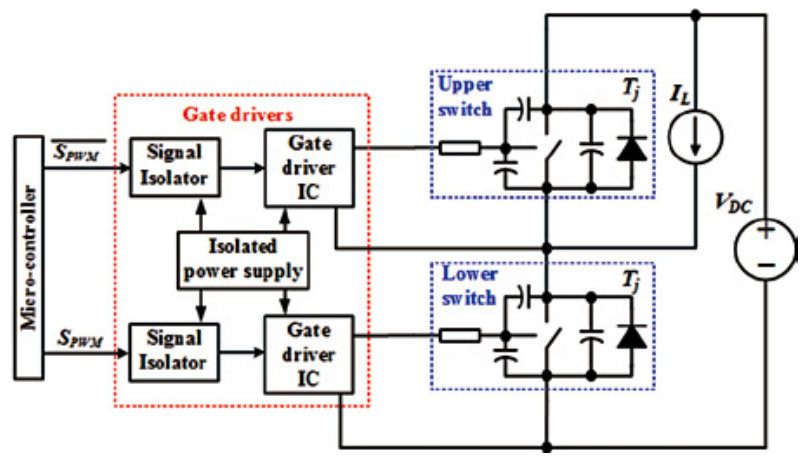

Fig. 8. Gate driver circuits in a phase-leg configuration.

Special attention needs to be paid to gate driver IC, since it directly interfaces with the gate terminals of power devices and is a key component to switching performance of power devices. There are three critical parameters for a gate driver IC that determine the gate driving capability, including pullup (-down) resistance of gate driver, rise (fall) time, and amplitude of gate driver output voltage. For SiC MOSFETs, considering the modest transconductance and relatively high Miller voltage as compared to the Si counterparts, the amplitude of gate driver output voltage plays a significant role on the switching behavior [101]. Based on this, an intelligent gate driver for $\mathrm{SiC}$ was proposed via actively tuning gate voltage during switching transient to enhance the gate driving capability to best serve SiC MOSFETs [102].

Additionally, signal isolator and isolated power supply can also become the limitations of the switching speed if the fast switching transient causes them to operate abnormally. In a phase-leg configuration, the ground of the secondary side of signal isolator and isolated power supply for the upper switch associated gate driver circuit swings from dc bus voltage to 0 when the states of power devices are changing. Therefore, the primary and secondary sides of isolation components suffer high $d v / d t$ during the switching transient. Meanwhile, the input-to-output parasitic capacitance offers a path to conduct CM noise induced by $d v / d t$ [103], [104]. In the end, pulse-width-modulation (PWM) signals from micro-controller will be interfered; and the output voltage quality of the isolated power supply will be affected. For $\mathrm{SiC}$ devices with high $d v / d t$ during fast switching, high $\mathrm{CM}$ noise immunity capability or low input-to-output parasitic capacitance is a critical selection criterion of signal isolator and isolated power supply.

To fully utilize the high operating temperature capability of SiC devices, their neighboring components must be capable of enduring high temperature. Considering that the gate driver circuits are preferred to be near the power devices for parasitic minimization, high temperature gate driver is an important design consideration. Currently, several gate drivers based on silicon on insulator (SOI) technology have been developed to operate at high temperature (e.g. $>200$ ${ }^{\circ} \mathrm{C}$ ). However, they are generally bulky and expensive [105], [106].

Furthermore, SiC gate drive design also faces several unique challenges due to the inherent properties of these emerging power devices. For example, for normallyoff SiC JFETs, the gate is not insulated from the channel by an oxide as MOSFETs, but forms a pn-junction with drain and source terminals, it is therefore required to inject hundreds of milliamps gate-source current during the onstate. On the other hand, during the switching transient, the gate drive should sink or source several amperes peak gate current to achieve fast switching [107]. To meet the different requirements for turn-on and turn-off switching transients on one hand and the steady on-state on the other hand, a gate driver with multiple driving stages should be designed [108].

\section{Protection}

Considering their intrinsic properties, $\mathrm{SiC}$ devices pose two unique challenges that can threaten the reliable operation of the power converters. One is the cross-talk among devices in a converter, e.g. between two devise in a voltage source converter (VSC) phase-leg, and the other is the limited overcurrent capability [109].

High $d v / d t$ during a fast switching transient of one device will affect the operating behavior of its complementary device in the same phase leg. This interaction between two switches is cross-talk. Specifically, during the turnon transient of the lower switch, as can be observed in Fig. 9(a), the positive charge stored in the Miller capacitance of the upper switch is transferred via its gate loop, inducing a positive spurious gate voltage. Thus, the upper switch may be partially turned on; and a shoot-through current will be generated, leading to additional switching losses in both switches and even shoot-through failure. On the other hand, during the turn-off transient of the lower switch, as shown in Fig. 9(b), the negative spurious voltage induced at the gate-source terminals of the upper switch may overstress the power device if its magnitude exceeds the maximum allowable negative gate voltage acceptable to the semiconductor device. With low threshold voltage, large internal gate resistance, and fast switching-speed, crosstalk is a clear hazard for safe operation of $\mathrm{SiC}$ devices in the VSC. Often, to avoid cross-talk, the high switchingspeed capability of SiC devices has to be compromised. To suppress cross-talk without sacrificing fast switching, several gate assist circuits were developed [102], [110]-[114]. Some are all transistor-based, which can be conveniently integrated with conventional gate driver IC [115], [116]. In the end, there is no extra complexity for end users.

Additionally, compared with Si devices, the short circuit protection of $\mathrm{SiC}$ MOSFETs is more challenging in several aspects. From thermal standpoint, SiC MOSFETs tend to have lower short circuit withstand capability, compared with Si IGBTs and MOSFETs, due to smaller chip area and higher current density [68]-[71]. The lower short circuit withstand capability requires a faster response time of the protection circuit to guarantee SiC MOSFETs operating within the safe operating areas (SOA). In addition to thermal breakdown, an overcurrent condition also has negative 


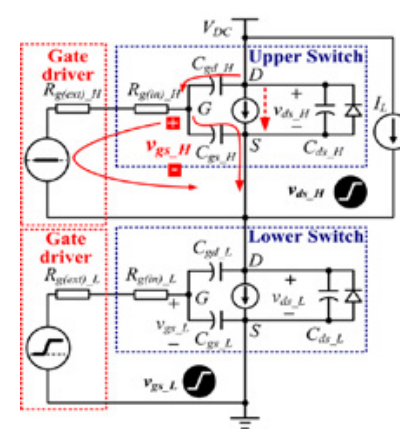

(a)

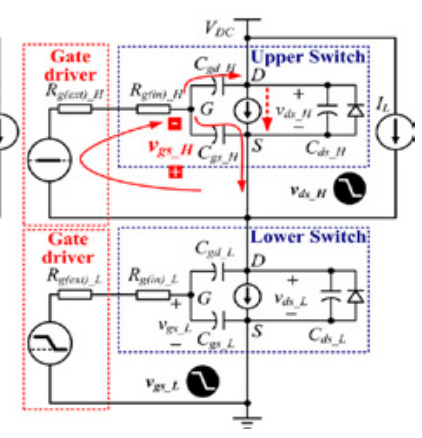

(b)
Fig. 9. Mechanisms causing cross-talk: (a) Turn-on transient; and (b) Turnoff transient.

impact on the long term stability of SiC MOSFETs, which had in the past suffered gate oxide reliability issues caused by poor interface quality [117]. Under high $d i / d t$ and $d v / d t$ condition, it is difficult for a short circuit protection scheme to achieve fast response time and strong noise immunity simultaneously. Currently, no IEEE standards or published work exists on the allowable response time for protection of WBG devices. A faster fault response time is always desirable to avoid device damage and/or degradation, as long as sufficient noise immunity can be guaranteed. To cope with this issue, a desaturation technique suitable for WBG devices was proposed to provide fast detection. It can help to clear a short-circuit fault within $200 \mathrm{~ns}$ [118]. Also note that several latest generation $\mathrm{SiC}$ MOSFETs with enhanced short-circuit withstand capability have been developed and demonstrated with more than $10 \mu$ s short-circuit sustaining time. But currently these devices are only available at medium voltage level. Also, to enhance the short-circuit withstand capability, device's switching performance often has to be compromised. Therefore, to maximize the benefits of $\mathrm{SiC}$ devices, the fast response short-circuit protection with strong noise immunity capability is always preferred.

Voltage spikes during switching transients can cause device breakdown. SiC devices with high switching-speed capability and small on-state resistance exacerbate the problem. Note also that compared with the overvoltage of the operating switch during the turn-off transient, which has been extensively investigated for Si devices, the voltage spikes of the non-operating switch in the same phase leg during the turn-on transient can be more severe for SiC devices [119]. Advanced packaging techniques and optimal layout design for parasitics minimization can relieve the overvoltage.

\section{Interaction with Loads}

High switching-speed of SiC devices leads to low switching loss and enables high switching frequency. However, high di/ $d t$ and $d v / d t$ during the fast switching transient worsens the electromagnetic environment of loads. In the meantime, fast switching makes the switching performance of $\mathrm{SiC}$ devices significantly susceptible to the loads' parasitics. In the end, the interaction between converter and load due to fast switching
SiC devices challenges the performance and reliability of the whole system.

First, voltage pulses with fast rise time generated by PWM switching of power devices can cause serious non-uniform voltage distribution in motor windings, and voltage doubling effect at motor terminals for motor loads with long power cables. The phenomenon is detrimental to motor insulation, and would require dedicated filter or special motor to mitigate. This is a well-known issue with $\mathrm{Si}$ device based PWM drives, and becomes more severe when $\mathrm{SiC}$ devices are utilized. Moreover, high $d v / d t$ induced by SiC devices can cause larger shaft voltage and bearing current in motor loads, detrimental to motor reliability.

Furthermore, high switching-speed performance of $\mathrm{SiC}$ devices will be affected by parasitics of loads. Fig. 10 depicts the impedance of $7.5-\mathrm{kW}$ induction motor plus 2-meter power cable with the frequency range from $10 \mathrm{kHz}$ to $100 \mathrm{MHz}$. It can be observed that the motor load is no longer inductive in the switching-related frequency range which is determined by the switching speed and typically at several $\mathrm{MHz}$ to tens of $\mathrm{MHz}$ for $\mathrm{SiC}$ devices considering switching intervals of tens of nanoseconds [120]. The load and cable parasitic impedances worsen the $\mathrm{SiC}$ devices' switching performance. It is reported that due to parasitics of the inductive load in Fig. 10, the tested switching time of $\mathrm{SiC}$ MOSFETs increases up to $42 \%$ during turn-on, and doubles during turn-off; an additional $32 \%$ of energy loss is dissipated during the switching transient. Also, for the higher power rating induction motor with longer power cable, the associated impedance at high frequency is even lower [121]. One solution to address this issue is to insert an auxiliary filter between converter and load to reshape the high frequency impedance of load such that parasitics of the load will "not be seen" or be masked from the converter side during the switching transient [122].

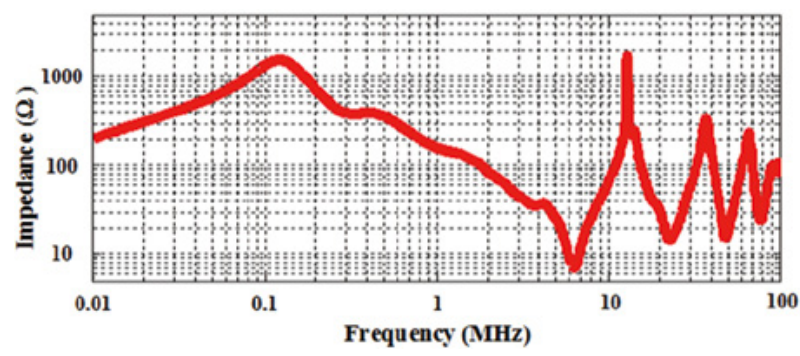

Fig. 10. High frequency impedance of $7.5-\mathrm{kW}$ induction motor plus 2-meter power cable.

\section{E. EMI Filter}

$\mathrm{SiC}$ devices with high switching frequency operation provide the opportunity to shrink the size of passive EMI filters. However, electromagnetic noise will also trend to concentrate in the high frequency range and increase filter design difficulties due to the non-ideal behaviors of passive components at high frequencies. When switching frequency is in the EMI standard range, the non-ideality of the passive filter, i.e. the equivalent parallel capacitance (EPC) of 
inductors and the equivalent series inductance (ESL) of capacitors and related self-resonant frequency, will present significant impact on filter insertion gain. This challenges the filter component design. Better winding schemes to reduce the EPC and better filter scheme to reduce inductance/ capacitance values and filter size to further reduce EPC and ESL, may be needed. Also, high frequency has more to do with the non-ideality of core material property, e.g. the widely used nanocrystalline core for $\mathrm{CM}$ choke has fast permeability drop above hundreds of $\mathrm{kHz}$. Better solution on choke design may be needed, such as combination of core materials associated with different frequency properties [123], combination of active and passive filters to cancel the lower frequency $\mathrm{CM}$ noise via active filter and reduce the needed value/size of passive filter to enhance its high frequency performance [124].

At high frequencies, the coupling effect of filter components through capacitive path and inductive path also becomes worse. In low switching frequency converters, though coupling exists, converter noise can be already attenuated considerably at the typical coupling frequency range. Whereas, in high switching frequency converters, since the main noise spectrum is in or closer to the range of coupling frequency, filter attenuation will be significantly degraded. Careful filter layout and component placement to mitigate the coupling, coupling cancellation schemes [125], or filter approaches that can avoid component coupling are desired.

\section{F. Thermal Management}

Generally, due to the highly-efficient $\mathrm{SiC}$ based power conversion system, less cooling is required. However, similar to the capacitive coupling effect within the power module, usually a thin layer of insulating material is used to separate the $\mathrm{SiC}$ devices from the electrically conductive heat sink. Thus, a parasitic capacitance is formed between the drain base plate of the $\mathrm{SiC}$ devices and the common heat sink plate, as shown in Fig. 11 [99]. In the end, this capacitance is paralleled with devices, which increases their effective output capacitance, and then negatively affects the switching speed.

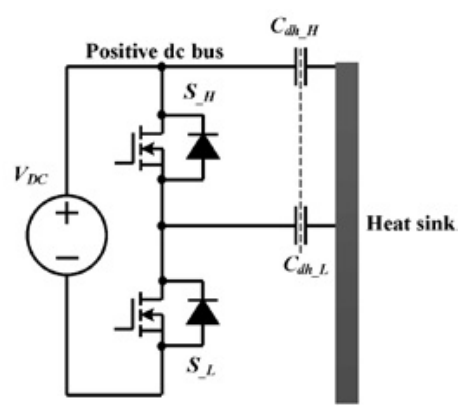

Fig. 11. Capacitive coupling between devices and heat sink.

The key reason for the capacitive coupling effect is the existence of a common heat sink for the upper and lower switches in the phase-leg. One approach to cancel the effect of capacitive coupling is to decouple the lower and upper switches to separate heat sinks, i.e. one heat sink is used for all upper switches and the other for all lower switches in the phase-leg [99].The method is effective only if two heat sinks can have different potentials.

\section{G. Control}

Control is an essential part of the power electronics converter system. There are many levels of controls. A suitable control architecture, based on the layered hierarchical control for high power converters, is recommended in [126] and illustrated in Fig. 12. There are many levels of controls, including hardware control layer, switching control layer, converter control layer, application control layer, and system control layer. Compared with the traditional Si based power conversion system, fast switching $\mathrm{SiC}$ devices pose several challenges, which are highlighted in Fig. 12 as well.

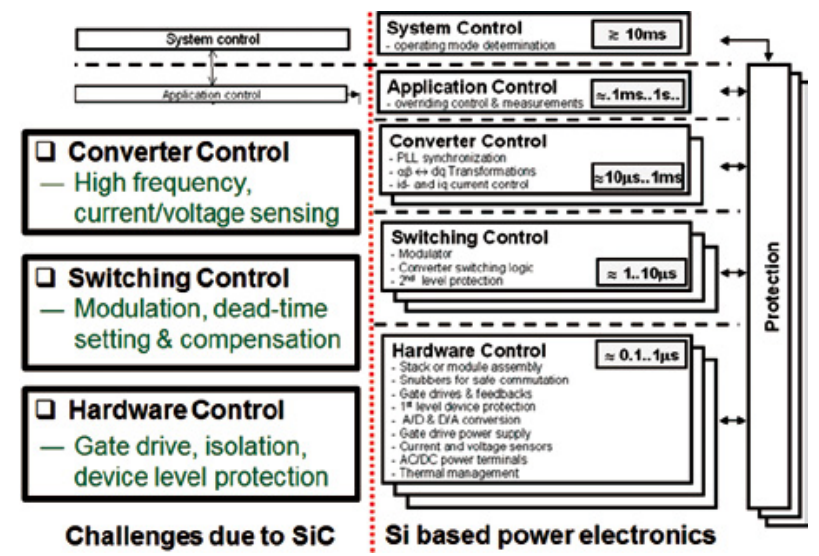

Fig. 12. Control architecture based on Si power electronics converter and challenges due to $\mathrm{SiC}$.

Hardware control layer: Manages everything specific to the power devices, such as gate drives and it may consist of multiple modules depending on the power requirements. For $\mathrm{SiC}$ devices, gate drive, isolation, and device level protection are challenging. Details are discussed in Parts B and C in this section. Also note that compared with $\mathrm{Si}$ devices with $0.1-1$ $\mu$ s control time in hardware control layer, fast switching $\mathrm{SiC}$ devices shorten it by a factor of 10 in the range of $0.01-0.1 \mu \mathrm{s}$.

Switching control layer: Enables the power electronics to behave as a switch-mode controlled source and includes modulation control and pulse generation. For SiC, modulation, especially considering the impact of dead-time for high frequency converter, is critical. More details are discussed as follows. Similar as the hardware control layer, the allowable control time for $\mathrm{SiC}$ devices becomes shorter.

Converter control layer: Enables the application control layer to perform its mission by implementing many of the functions common to all converters such as synchronous timing (phase-locked-loop), current and voltage filtering, measurements, and feedback control calculations. This layer will include the current control loop, which is independent of the application. Fast switching $\mathrm{SiC}$ enables higher switching 
frequency and control bandwidth, in the meantime, shortens the control algorithm execution time and challenges the computing capability of micro-controller. For $100 \mathrm{~s}$ of $\mathrm{kHz}$ to $\mathrm{MHz}$ switching frequency application, depending on the complexity of the control strategy, probably, the duty cycle (i.e. comparator value) of the PWM signal has to be updated per several switching cycles. Additionally, current/voltage sensing becomes highly susceptible to the noise introduced by high speed devices operating at high frequency. Detailed discussion of current/voltage sensing is presented as follows.

System and application control layers: System control layer covers all functions involved in the determination of the system mission and thus the duties of the power electronics system or their mode of operation. And application control layer dictates the operation of the power electronic system in order to meet the mission determined by the system control. Impact of $\mathrm{SiC}$ devices on these two control layers includes added functionalities as discussed in Section III.

Two unique challenges due to $\mathrm{SiC}$ devices with respect to control are highlighted as follows. It includes modulation with the consideration of dead-time effect and current/ voltage sensing.

\section{1) Dead-Time Setting and Compensation}

Modulation with the consideration of finite switching interval and associated dead-time effect significantly affect the performance of high frequency power conversion system. For example, turn-off time of $\mathrm{SiC}$ devices is highly sensitive to the operating conditions. As can be observed in Fig. 13, based on 1200-V/20 A SiC MOSFETs, compared to the tested turn-off time at the operating current of $20 \mathrm{~A}$, turn-off time at $5 \mathrm{~A}$ increases by a factor of 5 [102]. Thus, the traditional fixed dead-time depending on turn-off time at the worst operating point (i.e. 600-V/20-A in Fig. 13) is not suitable for $\mathrm{SiC}$ based voltage source converter. Also, for the SiC MOSFETs without SBD in parallel, the reverse conduction induced extra energy loss during the superfluous dead-time is significantly higher than the loss dissipated in the switch channel. Moreover, this reverse conduction loss is dissipated during each switching cycle and comparable to the switching loss [127]. Accordingly, dead-time setting for $\mathrm{SiC}$ devices is more critical as compared to the traditional $\mathrm{Si}$ counterparts. Adaptive dead-time regulation has been investigated to achieve the satisfactory tradeoff between efficiency and reliability [127].

Also, fast speed switching intensifies the impact of parasitics on switching commutation, and affects the power quality of the power converter. For example, when $\mathrm{SiC}$ based ac/dc converter is operated at high switching frequency, non-ideal voltage commutation becomes a key distortion factor for power quality control especially around each current zero crossing region. Also note that the parasitics of inductive load in practice significantly affect the switching commutation. Fig. 14 illustrates that under the same operating condition, turn-off time with the motor load is doubled as compared to that when an optimally-designed inductor load is employed [128]. This voltage ramping

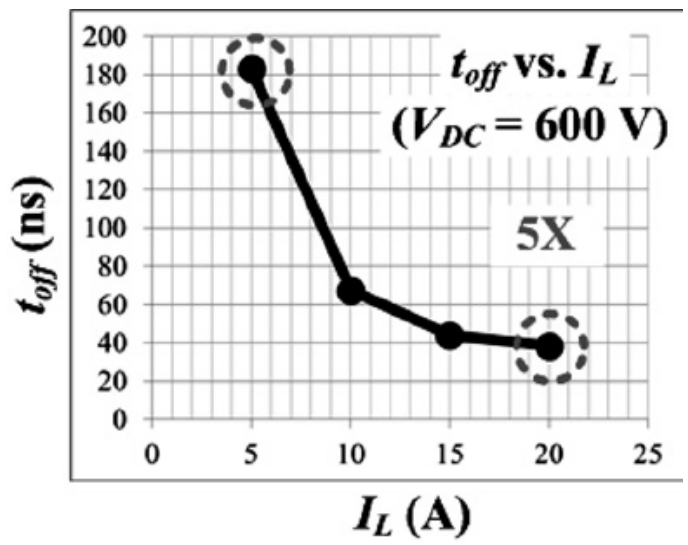

Fig. 13. Turn off time dependence on inductive load current.

introduces voltage loss compared to the ideal PWM voltage, leading to even harmonics for single phase ac/dc and $6 \mathrm{k} \pm 1$ order harmonics for three phase converter [129]. The higher the switching frequency is, the more severe voltage loss in a shorter switching period becomes. This effect shows the worst distortion in switch-diode configured converters such as Vienna-type rectifier, and it can also be accompanied with dead time effect or overlap time effect in phase-leg configured voltage source converters or current source converters. Compensation methods from voltage-second equivalence by adjusting duty cycle in each switching cycle [130] or by modulation compensation [129], [131], to feedback control [132]-[135] have been studied in recent years.

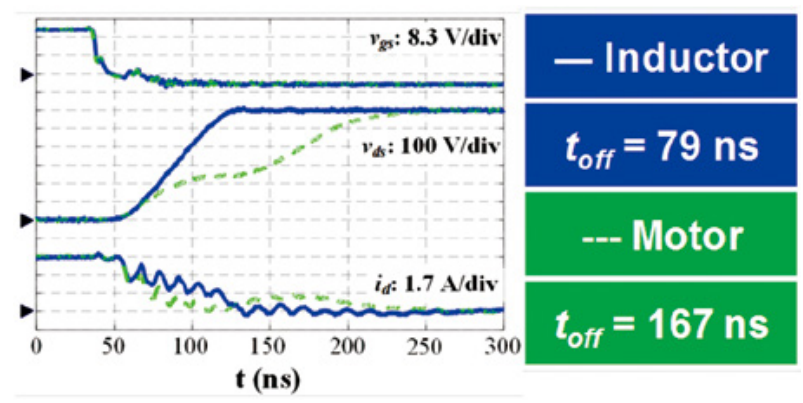

Fig. 14. Turn-off commutation time dependence on different inductive loads.

\section{2) Current/Voltage Sensing}

The integrity of current and voltage sensing signals is the basis for feedback control. However, a current sensor works normally at low switching speed in a typical Si based converter might be severely distorted under high-frequency high-speed conditions when $\mathrm{SiC}$ devices are adopted. It is found that for current sensors, the capacitive coupling due to high $d v / d t$ and magnetic coupling due to high $d i / d t$ from the $\mathrm{SiC}$ device switching node and loop, have impeded the effective control of current quality. Different approaches have been considered to mitigate these two distortion effects, such as better arrangement of sensor location (e.g. instead of placing the current senor to the terminal of the converter, one can put it on the other side of the inductor), selection of 
sensor with built-in capacitive shielding or applying proper exterior shielding, $d i / d t$ decoupling solutions, and etc.

\section{Conclusions And Future Trends}

This paper overviews the wide bandgap $\mathrm{SiC}$ technology. The focus is on the benefits, opportunities, and challenges with $\mathrm{SiC}$ based power electronics. The following observations and conclusions can be made and drawn from this paper:

1) With smaller size, lower loss, faster switching, and higher temperature capability, $\mathrm{SiC}$ devices can improve power conversion systems in several ways: by direct substitution of Si devices in existing circuits for improved efficiency and power density, by simplifying the circuit topology for reduced complexity and further enhanced power density, and by enabling system configuration modification for overall system power density improvement and lower cost.

2) In addition to the converter level benefits, $\mathrm{SiC}$ power electronics can further introduce system-level benefits as a result of fast switching capability and high available control bandwidth. The examples of system-level benefits include integrated harmonic filtering and stabilizer functions of the $\mathrm{SiC}$ based DER interface converters in a distribution grid or a microgrid.

3) $\mathrm{SiC}$ can also enable new power electronics applications that were previously not feasible with Si technology due to performance, cost, efficiency, reliability or density concerns. Examples include high-speed motor drive, SST, SSCB, and SSFCL. More emerging applications can be expected with $\mathrm{SiC}$ as a key enabling technology.

4) With faster switching, higher temperature, and smaller size, $\mathrm{SiC}$ also raise new design and application challenges. Gate drive and protection need to be faster and more adaptive. Loads can interfere with converter switching, therefore may require additional filters. High temperature and fast switching also demands better device packaging. Other challenges include thermal management, EMI filters, sensors and control. Many solutions have been and are being developed. However, the design and application methodology for $\mathrm{SiC}$ power electronics will remain an active research area for the foreseeable future.

Many of the advances presented in this paper are not yet mature and under rapid development. It is expected that $\mathrm{SiC}$ devices and related technologies will become mature, resulting in devices with lower cost, higher current ratings, better reliability, better gate drive and protection technologies, and more robust high temperature package. Consequently, they will be applied in more commercial power electronics converters.

One key to overcome adoption barrier of $\mathrm{SiC}$ and other WBG technologies is to train a new generation of engineers in the area of WBG power electronics. The U.S. DOE sponsored WBG Traineeship Program at University of Tennessee and Virginia Tech is a step in the right direction.

\section{ACKNOWLEDGEMENT}

The authors would like to thank Dr. Zhenxin Liang of Oak Ridge National Laboratory (ORNL) for materials on packaging, and Messrs. Bo Liu, Fei Yang, Jacob Dyer, Craig Timms, and Wen Zhang of CURENT at University of Tennessee for their help on colleting and organizing materials. The contributions by other colleagues from CURENT, GE Global Research, and CPES at Virginia Tech are acknowledged.

Some materials are based on research results of CURENT at University of Tennessee from projects sponsored by DOE, ORNL, and II-VI Foundation.

\section{REFERENCES}

[1] J. Millan, P. Godignon, X. Perpina, A. Perez-Tomas, and J. Rebollo, "A Survey of Wide Bandgap Power Semiconductor Devices," IEEE Transactions on Power Electronics, vol. 29, no. 5, pp. 2155-2163, 2014.

[2] F. Wang, Z. Zhang, T. Ericsen, R. Raju, R. Burgos, and D. Boroyevich, "Advances in Power Conversion and Drives for Shipboard Systems," Proceedings of the IEEE, vol. 103, no. 12, pp. 2285-2311, 2015.

[3] T. Lagier and P. Ladoux, "A comparison of insulated DC-DC converters for HVDC off-shore wind farms," in 2015 International Conference on Clean Electrical Power (ICCEP), 2015, pp. 33-39.

[4] P. Wolfs, Y. Fuwen, and H. Qing-Long, "Distribution level SiC FACTS devices with reduced DC bus capacitance for improved load capability and solar integration," in 2014 IEEE 23rd International Symposium on Industrial Electronics (ISIE), 2014, pp. 1353-1358.

[5] J. Hayes, K. George, P. Killeen, B. McPherson, K. J. Olejniczak, and T. R. McNutt, "Bidirectional, SiC Module-based Solid-State Circuit Breakers for 270 VDC MEA/AEA Systems," in IEEE Workshop on Wide Bandgap Power Devices and Applications, 2016.

[6] Y. Liu et al., "A silicon carbide fault current limiter for distribution systems," in 2014 IEEE Energy Conversion Congress and Exposition (ECCE), 2014, pp. 4972-4977.

[7] T. Daranagama, F. Udrea, T. Logan, and R. McMahon, "A performance comparison of $\mathrm{SiC}$ and $\mathrm{Si}$ devices in a bi-directional converter for distributed energy storage systems," in 2016 IEEE 7th International Symposium on Power Electronics for Distributed Generation Systems (PEDG), 2016, pp. 1-8.

[8] K. Kato, S. Ishiguma, Y. Ito, Y. Ohnuma, and S. Miyawaki, "Loss evaluation of matrix converters using SiC-MOSFETs for flywheel energy storage systems," in 2015 IEEE International Telecommunications Energy Conference (INTELEC), 2015, pp. 1-6.

[9] K. Mainali et al., "A Transformerless Intelligent Power Substation: A three-phase SST enabled by a $15-\mathrm{kV}$ SiC IGBT," IEEE Power Electronics Magazine, vol. 2, no. 3, pp. 31-43, 2015.

[10] D. Grider et al., " $10 \mathrm{kV} / 120 \mathrm{~A}$ SiC DMOSFET half H-bridge power modules for 1 MVA solid state power substation," in 2011 IEEE Electric Ship Technologies Symposium, 2011, pp. 131-134.

[11] H. Zhang and L. M. Tolbert, "Efficiency Impact of Silicon Carbide Power Electronics for Modern Wind Turbine Full Scale Frequency Converter," IEEE Transactions on Industrial Electronics, vol. 58, no. 1, pp. 21-28, 2011

[12] D. A. Marckx. Breakthrough in Power Electronics from SiC. [Online]. Available: http://www.nrel.gov/docs/fy06osti/38515.pdf

[13] H. Li. $50 \mathrm{~kW}$ transformerless SiC PV converter. [Online]. Available: http://curent.utk.edu/files/5814/6099/9289/Helen_Li_DOE_April_1. pdf

[14] R. Zhou, "GE MW SiC PV inverter development," in 2016 IEEE 43rd Photovoltaic Specialists Conference (PVSC), 2016, pp. 34703470 .

[15] U. Schwarzer, S. Buschhorn, and K. Vogel, "System Benefits for Solar Inverters using SiC Semiconductor Modules," in PCIM 
Europe 2014; International Exhibition and Conference for Power Electronics, Intelligent Motion, Renewable Energy and Energy Management, 2014, pp. 1-8.

[16] A. Anthon, Z. Zhang, M. A. E. Andersen, G. Holmes, B. McGrath, and C. A. Teixeira, "The Benefits of SiC MOSFETs in a T-Type Inverter for Grid-Tie Applications," IEEE Transactions on Power Electronics, vol. PP, no. 99, pp. 1-1, 2016.

[17] J. Boyd. Silicon Carbide Ready to Run the Rails. [Online]. Available: http://spectrum.iee.org/semiconductors/devices/silicon-carbideready-to-run-the-rails

[18] Mitsubishi Electric Delivers World's First SiC Auxiliary Power Supply Systems for Railcars. [Online]. Available: http://www. mitsubishielectric.com/news/2013/pdf/0326-a.pdf

[19] R. Lai et al., "A High Power Density Converter: Hardware Development Using SiC Devices," IEEE Industrial Electronics Magazine, vol. 4, no. 4, pp. 4-12, 2010.

[20] D. Zhang et al., "Development of an all $\mathrm{SiC}$ high power density three-phase rectifier with interleaving," in 2011 IEEE Energy Conversion Congress and Exposition, 2011, pp. 4073-4080.

[21] S. O. Donnell, J. L. Debauche, P. Wheeler, and A. Castellazzi, "Silicon carbide MOSFETs in more electric aircraft power converters: The performance and reliability benefits over silicon IGBTs for a specified flight mission profile," in 2016 18th European Conference on Power Electronics and Applications (EPE'16 ECCE Europe), 2016, pp. 1-10.

[22] T. Friedli, S. D. Round, and J. W. Kolar, "A 100 kHz SiC Sparse Matrix Converter," in 2007 IEEE Power Electronics Specialists Conference, 2007, pp. 2148-2154.

[23] A. Merkert, T. Krone, and A. Mertens, "Characterization and Scalable Modeling of Power Semiconductors for Optimized Design of Traction Inverters with Si- and SiC-Devices," IEEE Transactions on Power Electronics, vol. 29, no. 5, pp. 2238-2245, 2014.

[24] F. Hilpert, K. Brinkfeldt, and S. Arenz, "Modular integration of a $1200 \mathrm{v} \mathrm{SiC}$ inverter in a commercial vehicle wheel-hub drivetrain," in 2014 4th International Electric Drives Production Conference (EDPC), 2014, pp. 1-8

[25] K. Kumar, M. Bertoluzzo, and G. Buja, "Impact of SiC MOSFET traction inverters on compact-class electric car range," in 2014 IEEE International Conference on Power Electronics, Drives and Energy Systems (PEDES), 2014, pp. 1-6.

[26] A. Bucher et al., "Design of a full $\mathrm{SiC}$ voltage source inverter for electric vehicle applications," in 2016 18th European Conference on Power Electronics and Applications (EPE'16 ECCE Europe), 2016, pp. 1-10.

[27] McLaren. The relentless Drive for Power Density and Efficiency High Performance Electric Motors and Drives. [Online]. Available: http://www.mclaren.com/appliedtechnologies/case-study/relentlessdrive-power-density-and-efficiency

[28] Venturi Formula E. [Online]. Available: http://www.v-group.fr/ venturi-gp-formula-e-championship/

[29] Mitsubishi Electric Develops EV Motor Drive System with Builtin Silicon Carbide Inverter. [Online]. Available: http://www.mitsubishielectric.com/news/2014/pdf/0213-d.pdf

[30] A. Antonopoulos, H. Bangtsson, M. Alakula, and S. Manias, "Introducing a silicon carbide inverter for hybrid electric vehicles," in 2008 IEEE Power Electronics Specialists Conference, 2008, pp. 1321-1325.

[31] Y. Murakami, Y. Tajima, and S. Tanimoto, "Air-cooled full-SiC high power density inverter unit," in 2013 World Electric Vehicle Symposium and Exhibition (EVS27), 2013, pp. 1-4.

[32] I. Husain. New Tech Promises to Boost Electric Vehicle Efficiency, Range. [Online]. Available: https://news.ncsu.edu/2016/09/invertersboost-ev-range-2016/

[33] P. Crowe. Silicon Carbide Tested By Toyota To Save Energy In Its Future Hybrids. [Online]. Available: http://www.hybridcars. $\mathrm{com} /$ silicon-carbide-tested-by-toyota-to-save-energy-in-its-futurehybrids/

[34] B. Ozpineci, L. M. Tolbert, S. K. Islam, and M. Hasanuzzaman, "Effects of silicon carbide $(\mathrm{SiC})$ power devices on HEV PWM inverter losses," in Industrial Electronics Society, 2001. IECON '01. The 27th Annual Conference of the IEEE, 2001, vol. 2, pp. 1061-
1066 vol.2.

[35] H. Zhang, L. M. Tolbert, and B. Ozpineci, "Impact of SiC Devices on Hybrid Electric and Plug-In Hybrid Electric Vehicles," IEEE Transactions on Industry Applications, vol. 47, no. 2, pp. 912-921, 2011.

[36] S. Madhusoodhanan, K. Mainali, A. Tripathi, K. Vechalapu, and S. Bhattacharya, "Medium voltage $(>2.3 \mathrm{kV})$ high frequency threephase two-level converter design and demonstration using $10 \mathrm{kV}$ SiC MOSFETs for high speed motor drive applications," in 2016 IEEE Applied Power Electronics Conference and Exposition (APEC), 2016, pp. 1497-1504.

[37] J. Colmenares, D. Peftitsis, G. Tolstoy, D. Sadik, H. P. Nee, and J. Rabkowski, "High-efficiency three-phase inverter with $\mathrm{SiC}$ MOSFET power modules for motor-drive applications," in 2014 IEEE Energy Conversion Congress and Exposition (ECCE), 2014, pp. $468-474$

[38] T. Zhao, J. Wang, A. Q. Huang, and A. Agarwal, "Comparisons of SiC MOSFET and Si IGBT Based Motor Drive Systems," in 2007 IEEE Industry Applications Annual Meeting, 2007, pp. 331-335.

[39] F. Zare, D. Kumar, M. Lungeanu, and A. Andreas, "Electromagnetic interference issues of power, electronics systems with wide band gap, semiconductor devices," in 2015 IEEE Energy Conversion Congress and Exposition (ECCE), 2015, pp. 5946-5951.

[40] B. Whitaker, A. Barkley, Z. Cole, B. Passmore, T. McNutt, and A. B Lostetter, "A high-frequency, high-efficiency silicon carbide based phase-shifted full-bridge converter as a core component for a highdensity on-board vehicle battery charging system," in 2013 IEEE ECCE Asia Downunder, 2013, pp. 1233-1239.

[41] S. Srdic, C. Zhang, X. Liang, W. Yu, and S. Lukic, "A SiC-based power converter module for medium-voltage fast charger for plugin electric vehicles," in 2016 IEEE Applied Power Electronics Conference and Exposition (APEC), 2016, pp. 2714-2719.

[42] K. Martín, A. Rujas, I. Villar, I. Perez-de-Arenaza, and I. EtxeberriaOtadui, "Design of a $2.5 \mathrm{~kW}$ PFC boost full-SiC converter based on close-coupled inductors," in 2014 IEEE 15th Workshop on Control and Modeling for Power Electronics (COMPEL), 2014, pp. 1-7.

[43] L. Schrittwieser, J. W. Kolar, and T. B. Soeiro, "99\% efficient three-phase buck-type $\mathrm{SiC}$ MOSFET PFC rectifier minimizing life cycle cost in DC data centers," in 2016 IEEE International Telecommunications Energy Conference (INTELEC), 2016, pp. 1-8.

[44] T. J. Han, J. Preston, S. J. Jang, and D. Ouwerkerk, "A high density $3.3 \mathrm{~kW}$ isolated on-vehicle battery charger using SiC SBDs and SiC DMOSFETs," in 2014 IEEE Transportation Electrification Conference and Expo (ITEC), 2014, pp. 1-5.

[45] ABB revolutionizes battery charger for all trains - size reduced by a factor of 10. [Online]. Available: http://www.abb.com/cawp/ seitp202/d4e23b0eb8949cd0c125802e0031f941.aspx

[46] X. Xu et al., "Performance Evaluation of SiC MOSFET/BJT/ Schottky Diode in A $1 \mathrm{MHz}$ Single Phase PFC," in APEC 07 Twenty-Second Annual IEEE Applied Power Electronics Conference and Exposition, 2007, pp. 1268-1272.

[47] B. Lu, W. Dong, Q. Zhao, and F. C. Lee, "Performance evaluation of CoolMOS/sup /spl trade// and SiC diode for single-phase power factor correction applications," in Applied Power Electronics Conference and Exposition, 2003. APEC '03. Eighteenth Annual IEEE, 2003, vol. 2, pp. 651-657 vol.2.

[48] H. Zhang, L. M. Tolbert, B. Ozpineci, and M. S. Chinthavali, "A SiC-Based Converter as a Utility Interface for a Battery System," in Conference Record of the 2006 IEEE Industry Applications Conference Forty-First IAS Annual Meeting, 2006, vol. 1, pp. 346350 .

[49] F. Xu, B. Guo, L. M. Tolbert, F. Wang, and B. J. Blalock, "Design and performance of an all-SiC three-phase buck rectifier for high efficiency data center power supplies," in 2012 IEEE Energy Conversion Congress and Exposition (ECCE), 2012, pp. 2927-2933.

[50] P. Roussel, "SiC market and industruy update," presented at the Int. $\mathrm{SiC}$ Power Electron. Appl. Workshop, Kista, Sweden, 2011.

[51] A. Hefner et al., "Recent Advances in High-Voltage, HighFrequency Silicon-Carbide Power Devices," in Industry Applications Conference, 2006. 41st IAS Annual Meeting. Conference Record of the 2006 IEEE, 2006, vol. 1, pp. 330-337. 
[52] J. Wang, "Design, Characterization, Modeling and Analysis of High Voltage Silicon Carbide Power Devices," Ph.D., North Carolina State Univ., 2010.

[53] J. W. Palmour, "Silicon carbide power device development for industrial markets," in Electron Devices Meeting (IEDM), 2014 IEEE International, 2014, pp. 1.1.1-1.1.8.

[54] J. W. Palmour et al., "Silicon carbide power MOSFETs: Breakthrough performance from $900 \mathrm{~V}$ up to $15 \mathrm{kV}$," in Power Semiconductor Devices \& IC's (ISPSD), 2014 IEEE 26th International Symposium on, 2014, pp. 79-82.

[55] Rohm. [Online]. Available: http://www.rohm.com/web/global/ groups/-/group/groupname/SiC\%20Power\%20Devices

[56] Infineon. [Online]. Available: https:/www.infineon.com/cms/en/ product/power/sicarbide-sic/channel.html?channel=ff80808112ab68 1d0112ab6a50b304a0

[57] GeneSiC. [Online]. Available: http://www.genesicsemi.com/ commercial-sic/

[58] USCi. [Online]. Available: http://unitedsic.com/

[59] Microsemi Power Products Group. [Online]. Available: http://www. microsemi.com/product-directory/discretes/3613-silicon-carbide-sic

[60] Global Power Technologies Group. [Online]. Available: http://www. gptechgroup.com/index.php/en/

[61] Wolfspeed. [Online]. Available: http://www.wolfspeed.com/power/ products

[62] Monolith Semiconductor Inc. [Online]. Available: http://www. monolithsemi.com

[63] ST Micro. [Online]. Available: http://www.st.com/en/sic-devices. html

[64] Panasonic and Sansha Electric Jointly Develop A Compact SiC Power Module with Low Operating Loss. [Online]. Available: http://news.panasonic.com/global/press/data/2015/03/en150304-2/ en 150304-2.html

[65] L. Stevanovic. Industrial Readiness of SiC Power Devices. [Online] Available: https://www.rpi.edu/dept/cfes/AnnualConference/b2\%20 Stevanoic\%20GE.pdf

[66] J. B. Casady, T. McNutt, D. Girder, and J. Palmour, "Medium voltage SiC R\&D update," Wolfspeed, 2016.

[67] J. Hostetler, X. Li, P. Alexandrov, A. Bhalla, M. Becher, and J. Sherbondy, "6.5 kV Silicon Carbide JFETs siwtch module for high density power conversion system," EESAT Technical Conference, Sept., 2015.

[68] M. B. D. Othman, S. Lefebvre, A. Ibrahim, Z. Khatir, and A. Bouzourene, "Comparison study on performances and robustness between SiC MOSFET \& JFET devices-Abilities for aeronautics application," European Symposium on the Reliability of Electron Devices, Failure Physics and Analysis, vol. 52, pp. 1859-1964, 2012.

[69] Rohm, SiC power devices and modules. [Online]. Available: http:// rohmfs.rohm.com

[70] M. Treu et al., "Strategic Considerations for Unipolar SiC Switch Options: JFET vs. MOSFET," in Industry Applications Conference, 2007. 42nd IAS Annual Meeting. Conference Record of the 2007 IEEE, 2007, pp. 324-330.

[71] X. Huang, G. Wang, Y. Li, A. Q. Huang, and B. J. Baliga, "Shortcircuit capability of $1200 \mathrm{~V}$ SiC MOSFET and JFET for fault protection," in Applied Power Electronics Conference and Exposition (APEC), 2013 Twenty-Eighth Annual IEEE, 2013, pp. 197-200.

[72] C. DiMarino, W. Zhang, N. Haryani, Q. Wang, R. Burgos, and D. Boroyevich, "A High-Density, High-Efficiency $1.2 \mathrm{kV} \mathrm{SiC}$ MOSFET Module and Gate Drive Circuit," in IEEE Workshop on Wide Bandgap Power Devices and Applications, 2016.

[73] Powerex. Introduction to IPM. [Online]. Available: www.pwrx.com/ pwrx/app/IntellimodIntellPwrMods.pdf

[74] Powerex. SiC module PMF75CL1A120. [Online]. Available: http:// www.pwrx.com/Product/PMF75CL1A120

[75] Cree. Dual Channel Differential Isolated Gate Driver CGD15HB62LP. [Online]. Available: www.wolfspeed.com/media/ downloads/872/CGD15HB62LP.pdf

[76] AgileSwitch. Gate Driver EDEM3. [Online]. Available: http://www. agileswitch.com/sic-products.html

[77] Z. Wang et al., "A High Temperature Silicon Carbide mosfet Power
Module With Integrated Silicon-On-Insulator-Based Gate Drive,' IEEE Transactions on Power Electronics, vol. 30, no. 3, pp. 1432 1445,2015

[78] Z. Chen, Y. Yao, D. Boroyevich, K. D. T. Ngo, P. Mattavelli, and K Rajashekara, "A 1200-V, 60-A SiC MOSFET Multichip Phase-Leg Module for High-Temperature, High-Frequency Applications," IEEE Transactions on Power Electronics, vol. 29, no. 5, pp. 2307-2320, 2014.

[79] L. Zhang, S. Guo, X. Li, Y. Lei, W. Yu, and A. Q. Huang, "Integrated SiC MOSFET module with ultra low parasitic inductance for noise free ultra high speed switching," in 2015 IEEE 3rd Workshop on Wide Bandgap Power Devices and Applications (WiPDA), 2015, pp. 224-229.

[80] O. Kreutzer, B. Eckardt, and M. Maerz, "Optimum gate driver design to reach SiC-MOSFET's full potential Speeding up to 200 kV/us," in 2015 IEEE 3rd Workshop on Wide Bandgap Power Devices and Applications (WiPDA), 2015, pp. 41-46.

[81] J. Richmond. Hard-switched silicon IGBTs? cut switching losses in half with silicon carbide schottky diodes. [Online]. Available: http:// www.cree.com/ /media/Files/Cree/Power/Application\%20Notes/ CPWRAN03B.pdf

[82] B. Ozpineci, M. S. Chinthavali, L. M. Tolbert, A. S. Kashyap, and H. A. Mantooth, "A 55-kW Three-Phase Inverter With Si IGBTs and SiC Schottky Diodes," IEEE Transactions on Industry Applications, vol. 45, no. 1, pp. 278-285, 2009.

[83] F. Wang and L. M. Tolbert, "SiC high-speed MV direct drive vs. Si low-speed MV drive in compressor applications," presented at the HMW drive workshop II NIST, Gaithersburg, MD, 2014.

[84] "Next generation electric machines: magawatt class motors," pp. Department of Energy (DOE) Office of energy efficiency and renewable energy (EERE), Funding Opportunity Announcement (FOA) number: DE-FOA-0001208, 2015.

[85] N. Bottrell, M. Prodanovic, and T. C. Green, "Dynamic Stability of a Microgrid With an Active Load," IEEE Transactions on Power Electronics, vol. 28, no. 11, pp. 5107-5119, 2013.

[86] X. Wang, F. Blaabjerg, and W. Wu, "Modeling and Analysis of Harmonic Stability in an AC Power-Electronics-Based Power System," IEEE Transactions on Power Electronics, vol. 29, no. 12, pp. 6421-6432, 2014.

[87] W. McMurray, "The Thyristor Electronic Transformer: a Power Converter Using a High-Frequency Link," Industry and General Applications, IEEE Transactions on, vol. IGA-7, no. 4, pp. 451-457, 1971.

[88] A. Abramovitz and K. M. Smedley, "Survey of Solid-State Fault Current Limiters," Power Electronics, IEEE Transactions on, vol. 27, no. 6, pp. 2770-2782, 2012.

[89] J. Prigmore and G. Karady, "A novel $7.2 \mathrm{kV}$ fault current limiter for use in the FREEDM Project," in PES T\&D 2012, 2012, pp. 1-7.

[90] Z. Chen, D. Boroyevich, and R. Burgos, "Experimental parametric study of the parasitic inductance influence on MOSFET switching characteristics," in Power Electronics Conference (IPEC), 2010 International, 2010, pp. 164-169.

[91] D. Reusch and J. Strydom, "Understanding the effect of PCB layout on circuit performance in a high frequency gallium nitride based point of load converter," in Applied Power Electronics Conference and Exposition (APEC), 2013 Twenty-Eighth Annual IEEE, 2013, pp. 649-655.

[92] Z. Liang, P. Ning, F. Wang, and L. Marlino, "Planar bond all: A new packaging technology for advanced automotive power modules," in Energy Conversion Congress and Exposition (ECCE), 2012 IEEE, 2012, pp. 438-443.

[93] S. Li, L. M. Tolbert, F. Wang, and F. Z. Peng, "Stray Inductance Reduction of Commutation Loop in the P-cell and N-cell-Based IGBT Phase Leg Module," Power Electronics, IEEE Transactions on, vol. 29, no. 7, pp. 3616-3624, 2014.

[94] F. Yang, Z. Liang, Z. Wang, and F. Wang, "Design of a low parasitic inductance SiC power module with double-sided cooling," in IEEE Applied Power Electronics Conference, 2017.

[95] K. Takao and S. Kyogoku, "Ultra low inductance power module for fast switching SiC power devices," in 2015 IEEE 27th International Symposium on Power Semiconductor Devices \& IC's (ISPSD), 2015, 
pp. 313-316.

[96] H. Ishino, T. Watanabe, K. Sugiura, and K. Tsuruta, "6-in-1 Silicon carbide power module for high performance of power electronics systems," in 2014 IEEE 26th International Symposium on Power Semiconductor Devices \& IC's (ISPSD), 2014, pp. 446-449.

[97] L. D. Stevanovic, R. A. Beaupre, E. C. Delgado, and A. V. Gowda, "Low inductance power module with blade connector," in 2010 Twenty-Fifth Annual IEEE Applied Power Electronics Conference and Exposition (APEC), 2010, pp. 1603-1609.

[98] Z. Liang, "Status and trend of automotive power packaging," in Power Semiconductor Devices and ICs (ISPSD), 2012 24th International Symposium on, 2012, pp. 325-331.

[99] I. Josifović, J. Popović-Gerber, and J. A. Ferreira, "Improving SiC JFET Switching Behavior Under Influence of Circuit Parasitics," IEEE Transactions on Power Electronics, vol. 27, no. 8, pp. 3843$3854,2012$.

[100] R. Raju, "Silicon carbide high voltage, high frequency conversion," presented at the NIST High Megawatt Variable Speed Drive Technology Workshop, 2014.

[101] Z. Chen, D. Boroyevich, and J. Li, "Behavioral comparison of Si and $\mathrm{SiC}$ power MOSFETs for high-frequency applications," in Applied Power Electronics Conference and Exposition (APEC), 2013 Twenty-Eighth Annual IEEE, 2013, pp. 2453-2460.

[102] Z. Zhang, F. Wang, L. M. Tolbert, B. J. Blalock, and D. J. Costinett, "Active gate driver for fast switching and cross-talk suppression of SiC devices in a phase-leg configuration," in 2015 IEEE Applied Power Electronics Conference and Exposition (APEC), 2015, pp. 774-781.

[103] Z. Wei, H. Xiucheng, F. C. Lee, and L. Qiang, "Gate drive design considerations for high voltage cascode GaN HEMT," in Applied Power Electronics Conference and Exposition (APEC), 2014 Twenty-Ninth Annual IEEE, 2014, pp. 1484-1489.

[104] C. M. Zhen, "Keep Hybrid Powertrain Drives Noise Free by Rejecting dV/dt Noise With Isolated-Gate Drivers," Avago Technologies2008.

[105] Cissoid, HADES: High-Reliability, High-Temperature Half Bridge Isolated Gate-Driver, Datasheet. (2011). [Online]. Available: http:// www.cissoid.com/

[106] R. L. Greenwell, B. M. McCue, L. M. Tolbert, B. J. Blalock, and S. K. Islam, "High-temperature SOI-based gate driver IC for WBG power switches," in Applied Power Electronics Conference and Exposition (APEC), 2013 Twenty-Eighth Annual IEEE, 2013, pp. 1768-1775

[107] B. Wrzecionko, D. Bortis, J. Biela, and J. W. Kolar, "Novel ACCoupled Gate Driver for Ultrafast Switching of Normally Off $\mathrm{SiC}$ JFETs," Power Electronics, IEEE Transactions on, vol. 27, no. 7, pp. 3452-3463, 2012.

[108] J. Colmenares, D. Peftitsis, J. Rabkowski, D. P. Sadik, and H. P. Nee, "Dual-Function Gate Driver for a Power Module With SiC Junction Field-Effect Transistors," Power Electronics, IEEE Transactions on, vol. 29, no. 5, pp. 2367-2379, 2014

[109] Z. Zhang, Z. Wang, F. Wang, L. M. Tolbert, and B. J. Blalock, "Reliability-oriented design of gate driver for $\mathrm{SiC}$ devices in voltage source converter," in 2015 IEEE International Workshop on Integrated Power Packaging (IWIPP), 2015, pp. 20-23.

[110] Z. Zhang, F. Wang, L. M. Tolbert, and B. J. Blalock, "Active Gate Driver for Crosstalk Suppression of SiC Devices in a Phase-Leg Configuration," IEEE Transactions on Power Electronics, vol. 29, no. 4, pp. 1986-1997, 2014

[111] J. Wang and H. S. H. Chung, "A Novel RCD Level Shifter for Elimination of Spurious Turn-on in the Bridge-Leg Configuration," IEEE Transactions on Power Electronics, vol. 30, no. 2, pp. 976984, 2015.

[112] S. Yin, K. J. Tseng, C. F. Tong, R. Simanjorang, C. J. Gajanayake, and A. K. Gupta, "A novel gate assisted circuit to reduce switching loss and eliminate shoot-through in SiC half bridge configuration," in 2016 IEEE Applied Power Electronics Conference and Exposition (APEC), 2016, pp. 3058-3064.

[113] E. Velander, A. Löfgren, K. Kretschmar, and H. P. Nee, "Novel solutions for suppressing parasitic turn-on behaviour on lateral vertical JFETs," in 2014 16th European Conference on Power Electronics and Applications, 2014, pp. 1-8.
[114] Y. Zushi, S. Sato, K. Matsui, Y. Murakami, and S. Tanimoto, "A novel gate assist circuit for quick and stable driving of SiC-JFETs in a 3-phase inverter," in 2012 Twenty-Seventh Annual IEEE Applied Power Electronics Conference and Exposition (APEC), 2012, pp. 1734-1739.

[115] Rohm Semiconductor BM60015FV-LB. [Online]. Available: http:// www.rohm.com/web/global/products/-/product/BM60015FV-LB

[116] STMicroelectronics How to fine tune your SiC MOSFET gate driver to minimize losses. [Online]. Available: www.st.com/resource/en/ application note/dm00170577.pdf.

[117] L. C. Yu, G. T. Dunne, K. S. Matocha, K. P. Cheung, J. S. Suehle, and S. Kuang, "Reliability Issues of SiC MOSFETs: A Technology for High-Temperature Environments," Device and Materials Reliability, IEEE Transactions on, vol. 10, no. 4, pp. 418-426, 2010.

[118] Z. Wang, X. Shi, Y. Xue, L. M. Tolbert, F. Wang, and B. J. Blalock, "Design and Performance Evaluation of Overcurrent Protection Schemes for Silicon Carbide (SiC) Power MOSFETs," Industrial Electronics, IEEE Transactions on, vol. 61, no. 10, pp. 5570-5581, 2014.

[119] Z. Zhang, F. Wang, L. M. Tolbert, B. J. Blalock, and D. J. Costinett, "Understanding the limitations and impact factors of wide bandgap devices' high switching-speed capability in a voltage source converter," in Wide Bandgap Power Devices and Applications (WiPDA), 2014 IEEE Workshop on, 2014, pp. 7-12.

[120] Z. Zhang et al., "Methodology for switching characterization evaluation of wide band-gap devices in a phase-leg configuration," in Applied Power Electronics Conference and Exposition (APEC), 2014 Twenty-Ninth Annual IEEE, 2014, pp. 2534-2541.

[121] B. Mirafzal, G. L. Skibinski, R. M. Tallam, D. W. Schlegel, and R. A. Lukaszewski, "Universal Induction Motor Model With Low-toHigh Frequency-Response Characteristics," IEEE Transactions on Industry Applications, vol. 43, no. 5, pp. 1233-1246, 2007.

[122] Z. Zhang, "Characterization and realization of high switching-speed capability of $\mathrm{SiC}$ power devices in voltage source converter," $\mathrm{Ph} . \mathrm{D}$. The University of Tennessee, 2015.

[123] R. Lai, Y. Maillet, F. Wang, S. Wang, R. Burgos, and D. Boroyevich, "An Integrated EMI Choke for Differential-Mode and CommonMode Noise Suppression," IEEE Transactions on Power Electronics, vol. 25, no. 3, pp. 539-544, 2010.

[124] S. Wang, Y. Y. Maillet, F. Wang, D. Boroyevich, and R. Burgos, "Investigation of Hybrid EMI Filters for Common-Mode EMI Suppression in a Motor Drive System," IEEE Transactions on Power Electronics, vol. 25, no. 4, pp. 1034-1045, 2010.

[125] S. Wang, F. C. Lee, and J. D. v. Wyk, "A Study of Integration of Parasitic Cancellation Techniques for EMI Filter Design With Discrete Components," IEEE Transactions on Power Electronics, vol. 23, no. 6, pp. 3094-3102, 2008.

[126] "IEEE Guide for Control Architecture for High Power Electronics (1 MW and Greater) Used in Electric Power Transmission and Distribution Systems," IEEE Std 1676-2010, pp. 1-47, 2011.

[127] Z. Zhang, F. Wang, D. J. Costinett, L. M. Tolbert, B. J. Blalock, and L. Haifeng, "Dead-time optimization of $\mathrm{SiC}$ devices for voltage source converter," in 2015 IEEE Applied Power Electronics Conference and Exposition (APEC), 2015, pp. 1145-1152.

[128] Z. Zhang, F. Wang, L. M. Tolbert, B. J. Blalock, and D. J. Costinett, "Evaluation of Switching Performance of SiC Devices in PWM Inverter-Fed Induction Motor Drives," IEEE Transactions on Power Electronics, vol. 30, no. 10, pp. 5701-5711, 2015.

[129] B. Liu, R. Ren, E. A. Jones, F. Wang, D. Costinett, and Z. Zhang, "A compensation scheme to reduce input current distortion in $\mathrm{GaN}$ based $450 \mathrm{kHz}$ three-phase Vienna type PFC," in IEEE Energy Conversion Congress and Exposition, 2016.

[130] Z. Zhang and L. Xu, "Dead-Time Compensation of Inverters Considering Snubber and Parasitic Capacitance," IEEE Transactions on Power Electronics, vol. 29, no. 6, pp. 3179-3187, 2014.

[131] M. Hartmann, H. Ertl, and J. W. Kolar, "On the Tradeoff Between Input Current Quality and Efficiency of High Switching Frequency PWM Rectifiers," IEEE Transactions on Power Electronics, vol. 27, no. 7, pp. 3137-3149, 2012.

[132] N. Bedetti, S. Calligaro, and R. Petrella, "Self-Commissioning of Inverter Dead-Time Compensation by Multiple Linear Regression 
Based on a Physical Model," IEEE Transactions on Industry Applications, vol. 51, no. 5, pp. 3954-3964, 2015.

[133] C. Li et al., "Analysis and compensation of dead-time effect considering parasitic capacitance and ripple current," in 2015 IEEE Applied Power Electronics Conference and Exposition (APEC), 2015, pp. 1501-1506.

[134] J. Yuan et al., "An Immune-Algorithm-Based Dead-Time Elimination PWM Control Strategy in a Single-Phase Inverter," IEEE Transactions on Power Electronics, vol. 30, no. 7, pp. 3964$3975,2015$.

[135] B. Guo et al., "Compensation of input current distortion in threephase buck rectifiers," in 2013 Twenty-Eighth Annual IEEE Applied Power Electronics Conference and Exposition (APEC), 2013, pp. 930-938.

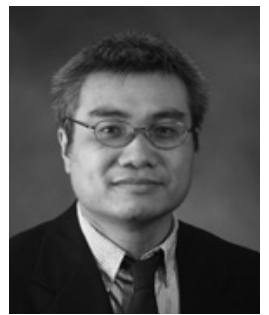

Fei (Fred) Wang received the B.S. degree from Xi'an Jiaotong University, Xi'an, China, and the M.S. and Ph.D. degrees from the University of Southern California, Los Angeles, in 1982, 1985, and 1990, respectively, all in electrical engineering.

Dr. Wang was a Research Scientist in the Electric Power Lab, University of Southern California, from 1990 to 1992 . He joined the GE Power Systems Engineering Department, Schenectady, NY, as an Application Engineer in 1992. From 1994 to 2000, he was a Senior Product Development Engineer with GE Industrial Systems, Salem, VA. During 2000 to 2001, he was the Manager of Electronic \& Photonic Systems Technology Lab, GE Global Research Center, Schenectady, NY and Shanghai, China. In 2001, he joined the Center for Power Electronics Systems (CPES) at Virginia Tech, Blacksburg, VA as a Research Associate Professor and became an Associate Professor in 2004. From 2003, he also served as the CPES Technical Director. Since 2009, he has been with The University of Tennessee and Oak Ridge National Lab, Knoxville, TN as a Professor and Condra Chair of Excellence in Power Electronics. He is a founding member and Technical Director of the multi-university NSF/DOE Engineering Research Center for Ultra-wide-area Resilient Electric Energy Transmission Networks (CURENT) led by The University of Tennessee. His research interests include power electronics, power systems, controls, electric machines and motor drives.

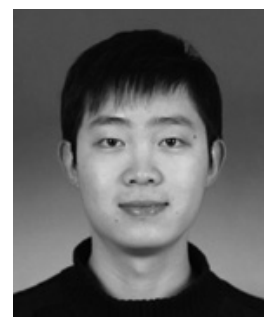

Zheyu Zhang received the B.S. and M.S. degrees from Huazhong University of Science and Technology, Wuhan, China, and Ph.D. degrees from The University of Tennessee, Knoxville, TN, in 2008,2011 , and 2015, respectively, all in electrical engineering. He is currently the research assistant professor in Electrical Engineering and Computer Science, The University of Tennessee. His research interests include wide band-gap semiconductors and application, gate driver technology, motor drive design, operation, integration and reliability, cryogenic power electronics. 